Supporting Information for

\title{
Alkylation of Inorganic Oxo Compounds and Insights on Preventing DNA Damage
}

\author{
Elizabeth E. Hamilton, Phillip E. Fanwick, and Jonathan J. Wilker* \\ Department of Chemistry, Purdue University \\ 560 Oval Dr., West Lafayette, IN 47907-2084
}

Figure S1. $\quad{ }^{1} \mathrm{H}$ NMR spectrum of $50 \mathrm{mM}\left[\left(\mathrm{C}_{4} \mathrm{H}_{9}\right)_{4} \mathrm{~N}\right]_{3}\left(\mathrm{~V}_{3} \mathrm{O}_{9}\right)$ with 1 equiv $\left(\mathrm{CH}_{3} \mathrm{CH}_{2} \mathrm{O}\right)_{2} \mathrm{SO}_{2}$ in $\mathrm{CD}_{3} \mathrm{CN}$

Figure S2. $\quad{ }^{1} \mathrm{H} N M R$ spectrum of $50 \mathrm{mM}\left[\left(\mathrm{C}_{4} \mathrm{H}_{9}\right)_{4} \mathrm{~N}\right]_{3}\left(\mathrm{~V}_{3} \mathrm{O}_{9}\right)$ with 1 equiv $N$-ethyl- $N$-nitrosourea in $\mathrm{CD}_{3} \mathrm{CN}$

Figure S3. $\quad{ }^{51} \mathrm{~V}$ NMR spectrum of $50 \mathrm{mM}\left[\left(\mathrm{C}_{4} \mathrm{H}_{9}\right)_{4} \mathrm{~N}\right]_{3}\left(\mathrm{~V}_{3} \mathrm{O}_{9}\right)$ with 1 equiv $N$-ethyl- $N$-nitrosourea in $\mathrm{CD}_{3} \mathrm{CN}$

Figure S4. $\quad{ }^{51} \mathrm{~V}$ NMR spectra of $50 \mathrm{mM}\left[\left(\mathrm{C}_{4} \mathrm{H}_{9}\right)_{4} \mathrm{~N}\right]_{3}\left(\mathrm{HV}_{4} \mathrm{O}_{12}\right)$ alone and with 1 equiv $\left(\mathrm{CH}_{3} \mathrm{CH}_{2} \mathrm{O}\right)_{2} \mathrm{SO}_{2}$ in $\mathrm{CD}_{3} \mathrm{CN}$

Figure S5. $\quad{ }^{51} \mathrm{~V}$ NMR spectra of $50 \mathrm{mM}\left[\left(\mathrm{C}_{4} \mathrm{H}_{9}\right)_{4} \mathrm{~N}\right]_{3}\left(\mathrm{~V}_{5} \mathrm{O}_{14}\right)$ alone and with 1 equiv $\left(\mathrm{CH}_{3} \mathrm{CH}_{2} \mathrm{O}\right)_{2} \mathrm{SO}_{2}$ in $\mathrm{CD}_{3} \mathrm{CN}$

Figure S6. $\quad{ }^{51} \mathrm{~V}$ NMR spectra of $50 \mathrm{mM}\left[\left(\mathrm{C}_{4} \mathrm{H}_{9}\right)_{4} \mathrm{~N}\right]_{3}\left(\mathrm{H}_{3} \mathrm{~V}_{10} \mathrm{O}_{28}\right)$ alone and with 1 equiv $\left(\mathrm{CH}_{3} \mathrm{CH}_{2} \mathrm{O}\right)_{2} \mathrm{SO}_{2}$ in $\mathrm{CD}_{3} \mathrm{CN}$

Figure S7. $\quad{ }^{51} \mathrm{~V}$ NMR spectra of $50 \mathrm{mM}\left[\left(\mathrm{C}_{4} \mathrm{H}_{9}\right)_{4} \mathrm{~N}\right]_{4}\left(\mathrm{~V}_{10} \mathrm{O}_{26}\right)$ alone and with 1 equiv $\left(\mathrm{CH}_{3} \mathrm{CH}_{2} \mathrm{O}\right)_{2} \mathrm{SO}_{2}$ in $\mathrm{CD}_{3} \mathrm{CN}$

Figure S8. $\quad{ }^{1} \mathrm{H}$ NMR spectrum of $25 \mathrm{mM}\left[\left(\mathrm{C}_{6} \mathrm{H}_{5}\right)_{4} \mathrm{P}\right]_{3}\left(\mathrm{O}_{3} \mathrm{SeOCH}_{2} \mathrm{OSeO}_{3}\right)\left(\mathrm{HSeO}_{4}\right)$ in $\mathrm{CD}_{3} \mathrm{CN}$

Figure S9. $\quad{ }^{77} \mathrm{Se} N M R$ proton coupled spectrum of $25 \mathrm{mM}\left[\left(\mathrm{C}_{6} \mathrm{H}_{5}\right)_{4} \mathrm{P}\right]_{3}\left(\mathrm{O}_{3} \mathrm{SeOCH}_{2} \mathrm{OSeO}_{3}\right)\left(\mathrm{HSeO}_{4}\right)$ in $\mathrm{CD}_{3} \mathrm{CN}$

Figure S10. $\quad{ }^{1} \mathrm{H}$ NMR spectrum of $25 \mathrm{mM}\left[\left(\mathrm{C}_{6} \mathrm{H}_{5}\right)_{4} \mathrm{P}\right]_{3}\left(\mathrm{O}_{3} \mathrm{SeOCH}_{2} \mathrm{OSeO}_{3}\right)\left(\mathrm{HSeO}_{4}\right)$ with 1 equiv of $N$-ethyl- $N$ nitrosourea in $\mathrm{CD}_{3} \mathrm{CN}$

Figure S11. $\quad{ }^{1} \mathrm{H}$ NMR spectra of $25 \mathrm{mM}\left[\left(\mathrm{C}_{6} \mathrm{H}_{5}\right)_{4} \mathrm{P}\right]_{3}\left(\mathrm{O}_{3} \mathrm{SeOCH}_{2} \mathrm{OSeO}_{3}\right)\left(\mathrm{HSeO}_{4}\right)$ alone, with 1 equiv $\left(\mathrm{CH}_{3} \mathrm{CH}_{2} \mathrm{O}\right)_{2} \mathrm{SO}_{2}$, with 1 equiv $\mathrm{CH}_{3} \mathrm{CH}_{2} \mathrm{OSO}_{2} \mathrm{CF}_{3}$ in $\mathrm{CD}_{3} \mathrm{CN}$

Figure S12. $\quad{ }^{77} \mathrm{Se} N M R$ proton decoupled spectra of $25 \mathrm{mM}\left[\left(\mathrm{C}_{6} \mathrm{H}_{5}\right)_{4} \mathrm{P}\right]_{3}\left(\mathrm{O}_{3} \mathrm{SeOCH}_{2} \mathrm{OSeO}_{3}\right)\left(\mathrm{HSeO}_{4}\right)$ alone, with 1 equiv $\left(\mathrm{CH}_{3} \mathrm{CH}_{2} \mathrm{O}\right)_{2} \mathrm{SO}_{2}$, with 1 equiv $\mathrm{CH}_{3} \mathrm{CH}_{2} \mathrm{OSO}_{2} \mathrm{CF}_{3}$ in $\mathrm{CD}_{3} \mathrm{CN}$

Figure S13. $\quad{ }^{1} \mathrm{H}$ NMR spectra of ethyl phosphate controls

Figure S14. $\quad{ }^{31}$ P NMR spectra of ethyl phosphate controls

Section S1. Detailed explanation of NMR peak assignments for phosphate alkylation products

Table S1. Experimental procedures for X-ray crystal structure determination of $\left[\left(\mathrm{C}_{6} \mathrm{H}_{5}\right)_{4} \mathrm{P}\right]_{3}\left(\mathrm{O}_{3} \mathrm{SeOCH}_{2} \mathrm{OSeO}_{3}\right)\left(\mathrm{HSeO}_{4}\right)$

Table S2. Crystal data and data collection parameters for $\left[\left(\mathrm{C}_{6} \mathrm{H}_{5}\right)_{4} \mathrm{P}\right]_{3}\left(\mathrm{O}_{3} \mathrm{SeOCH}_{2} \mathrm{OSeO}_{3}\right)\left(\mathrm{HSeO}_{4}\right)$

Table S3. Positional parameters for $\left[\left(\mathrm{C}_{6} \mathrm{H}_{5}\right)_{4} \mathrm{P}\right]_{3}\left(\mathrm{O}_{3} \mathrm{SeOCH}_{2} \mathrm{OSeO}_{3}\right)\left(\mathrm{HSeO}_{4}\right)$

Table S4. Thermal parameters for $\left[\left(\mathrm{C}_{6} \mathrm{H}_{5}\right)_{4} \mathrm{P}\right]_{3}\left(\mathrm{O}_{3} \mathrm{SeOCH}_{2} \mathrm{OSeO}_{3}\right)\left(\mathrm{HSeO}_{4}\right)$ 


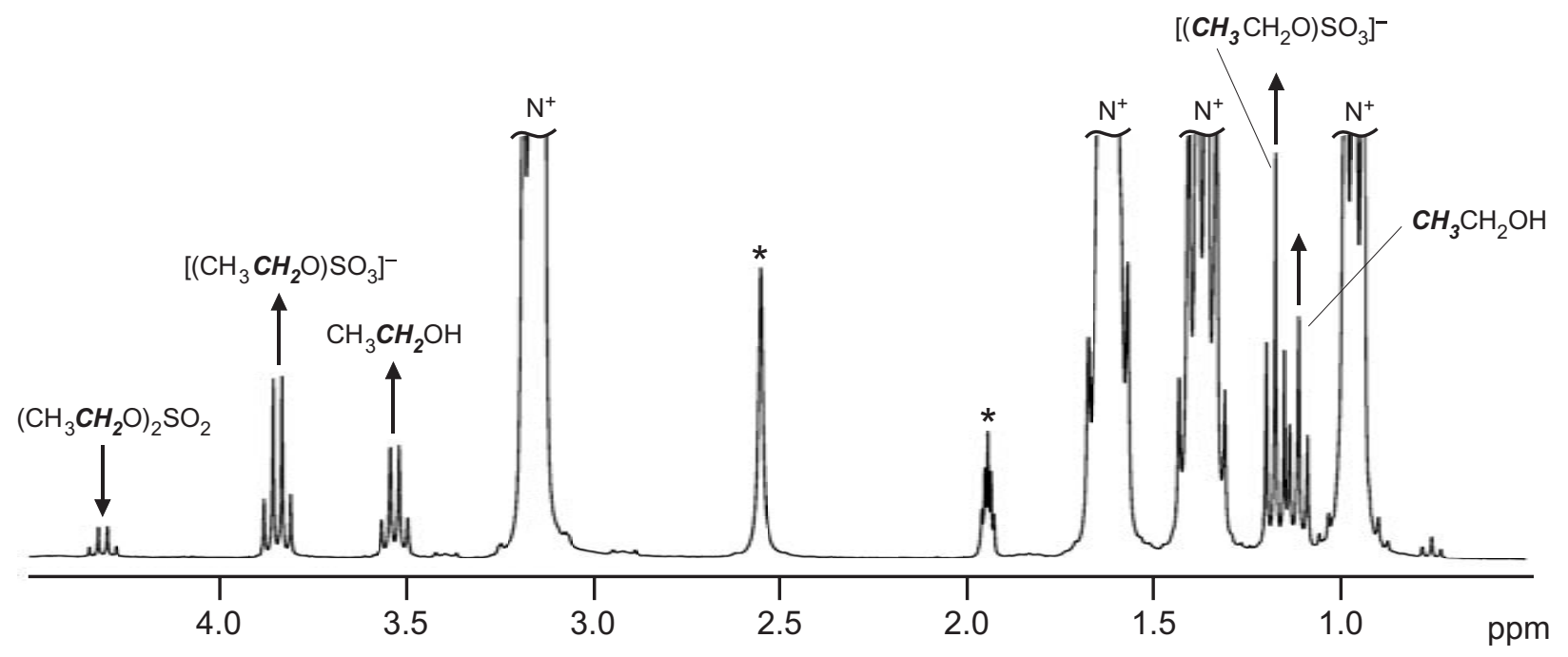

Figure S1. ${ }^{1} \mathrm{H}$ NMR spectrum of the $1: 1$ reaction (50 $\mathrm{mM}$ each), in progress (135 min), between $\left[\left(\mathrm{C}_{4} \mathrm{H}_{9}\right)_{4} \mathrm{~N}\right]_{3}\left(\mathrm{~V}_{3} \mathrm{O}_{9}\right)$ and $\left(\mathrm{CH}_{3} \mathrm{CH}_{2} \mathrm{O}\right)_{2} \mathrm{SO}_{2}$ in $\mathrm{CD}_{3} \mathrm{CN}$. Arrows indicate changes in the spectrum related to consumption of starting reagents. Solvent and water peaks are marked with a "*." The $\left[\left(\mathrm{C}_{4} \mathrm{H}_{9}\right)_{4} \mathrm{~N}\right]^{+}$peaks are designated by " $\mathrm{N}^{+}$." 


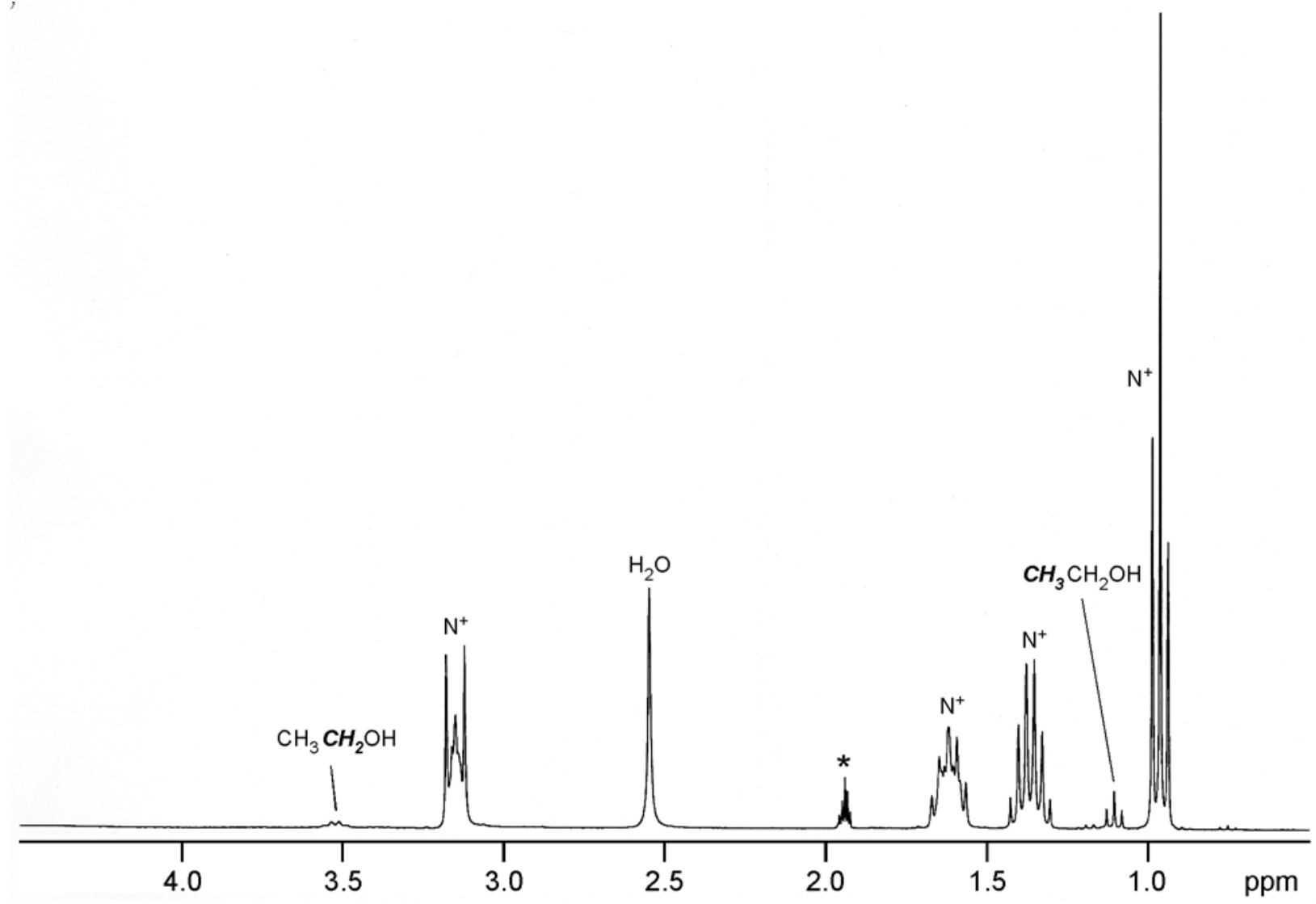

Figure S2. ${ }^{1} \mathrm{H}$ NMR spectrum of the $1: 1$ reaction $\left(50 \mathrm{mM}\right.$ each) between $\left[\left(\mathrm{C}_{4} \mathrm{H}_{9}\right)_{4} \mathrm{~N}\right]_{3}\left(\mathrm{~V}_{3} \mathrm{O}_{9}\right)$ and $N$-ethyl- $N$-nitrosourea in $\mathrm{CD}_{3} \mathrm{CN}$ after $15 \mathrm{~min}$. Solvent peak is marked with a "**." The $\left[\left(\mathrm{C}_{4} \mathrm{H}_{9}\right)_{4} \mathrm{~N}\right]^{+}$peaks are designated by " $\mathrm{N}^{+}$." 


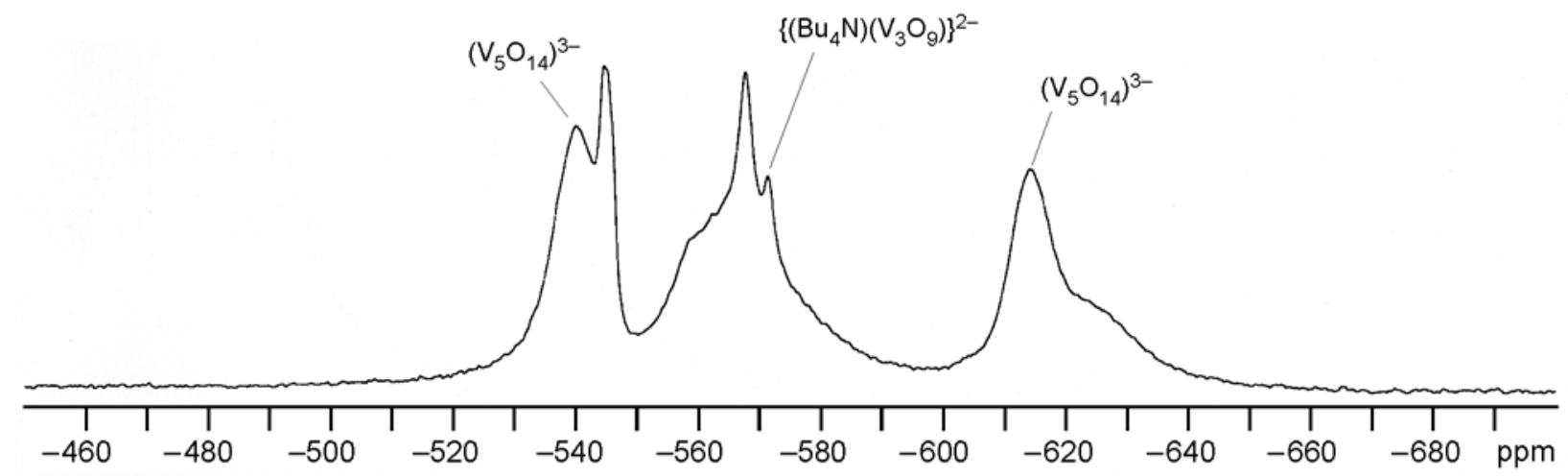

Figure S3. ${ }^{51} \mathrm{~V}$ NMR spectrum of the $1: 1$ reaction $\left(50 \mathrm{mM}\right.$ each) between $\left[\left(\mathrm{C}_{4} \mathrm{H}_{9}\right)_{4} \mathrm{~N}\right]_{3}\left(\mathrm{~V}_{3} \mathrm{O}_{9}\right)$ and $N$-ethyl- $N$-nitrosourea in $\mathrm{CD}_{3} \mathrm{CN}$ after $15 \mathrm{~min}$. 


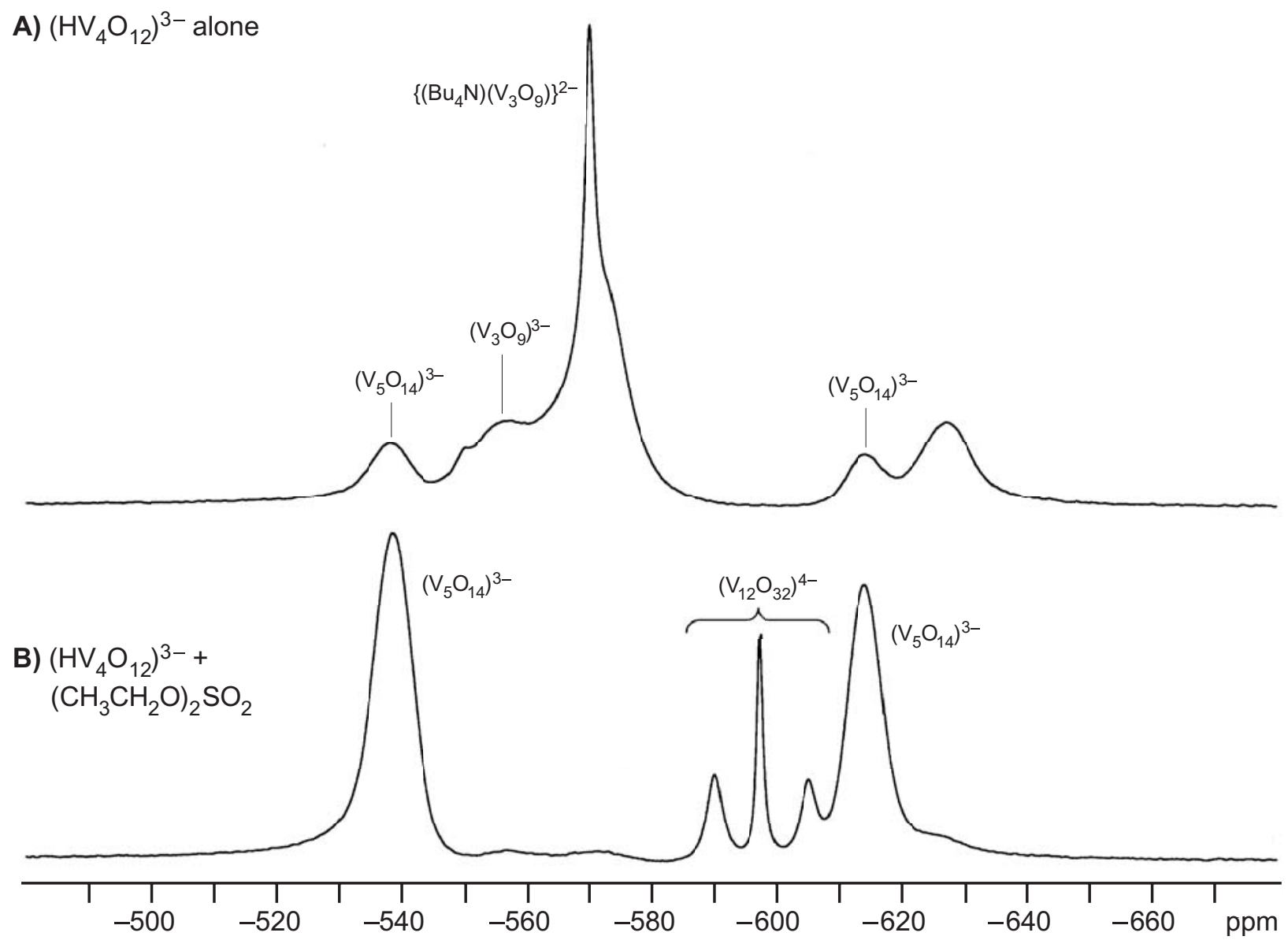

Figure S4. ${ }^{51} \mathrm{~V}$ NMR spectra of $50 \mathrm{mM}\left[\left(\mathrm{C}_{4} \mathrm{H}_{9}\right)_{4} \mathrm{~N}_{3}\left(\mathrm{HV}_{4} \mathrm{O}_{12}\right)\right.$ in $\left.\mathrm{CD}_{3} \mathrm{CN} \mathrm{A}\right)$ alone and B) with 1 equiv $\left(\mathrm{CH}_{3} \mathrm{CH}_{2} \mathrm{O}\right)_{2} \mathrm{SO}_{2}$ at $31 \mathrm{~h}$. 
A) $\left(\mathrm{V}_{5} \mathrm{O}_{14}\right)^{3-}$ alone

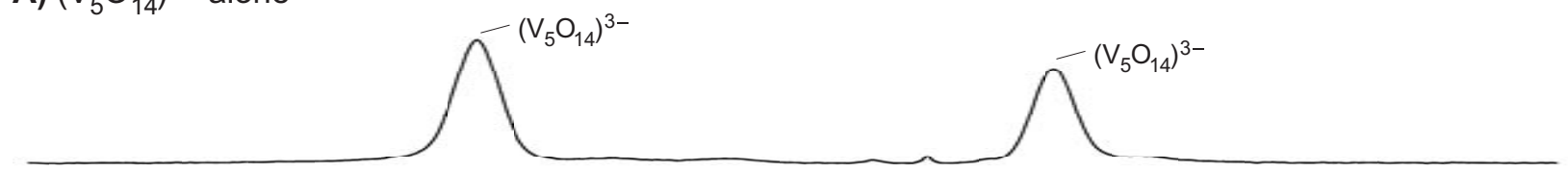

B) $\left(\mathrm{V}_{5} \mathrm{O}_{14}\right)^{3-}+\left(\mathrm{CH}_{3} \mathrm{CH}_{2} \mathrm{O}\right)_{2} \mathrm{SO}_{2}$

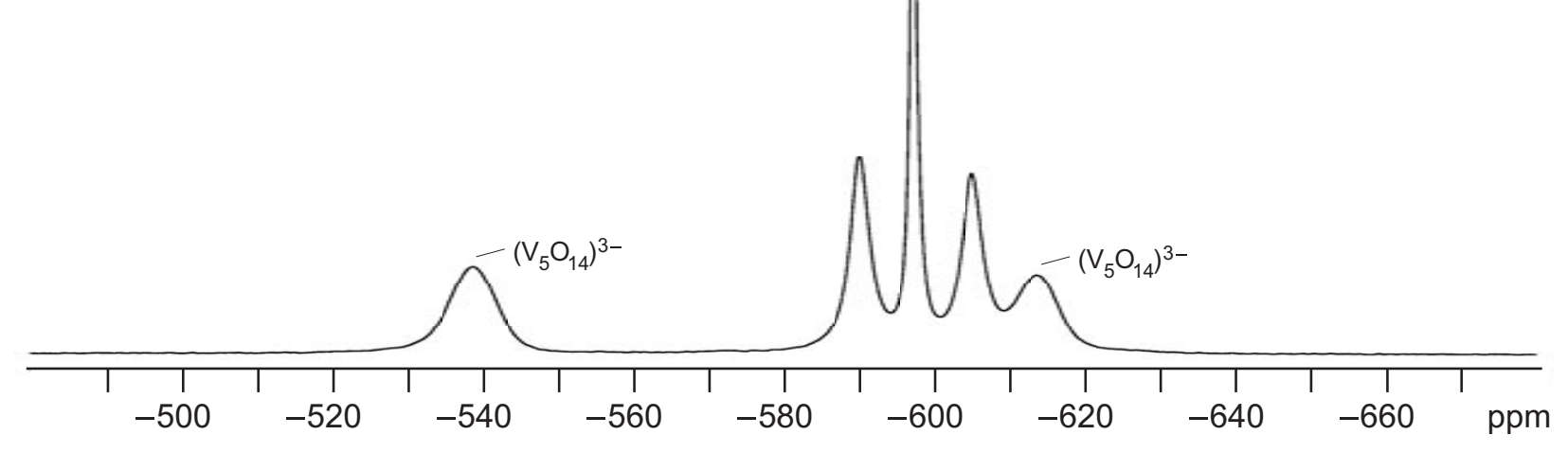

Figure S5. ${ }^{51} \mathrm{~V}$ NMR spectra of $\left[\left(\mathrm{C}_{4} \mathrm{H}_{9}\right)_{4} \mathrm{~N}\right]_{3}\left(\mathrm{~V}_{5} \mathrm{O}_{14}\right)$ in $\left.\mathrm{CD}_{3} \mathrm{CN} \mathrm{A}\right)$ alone $(25 \mathrm{mM})$ and $\left.\mathrm{B}\right)$ with 1 equiv $\left(\mathrm{CH}_{3} \mathrm{CH}_{2} \mathrm{O}\right)_{2} \mathrm{SO}_{2}(50 \mathrm{mM}$ each) at $\sim 3 \mathrm{~d}$. 


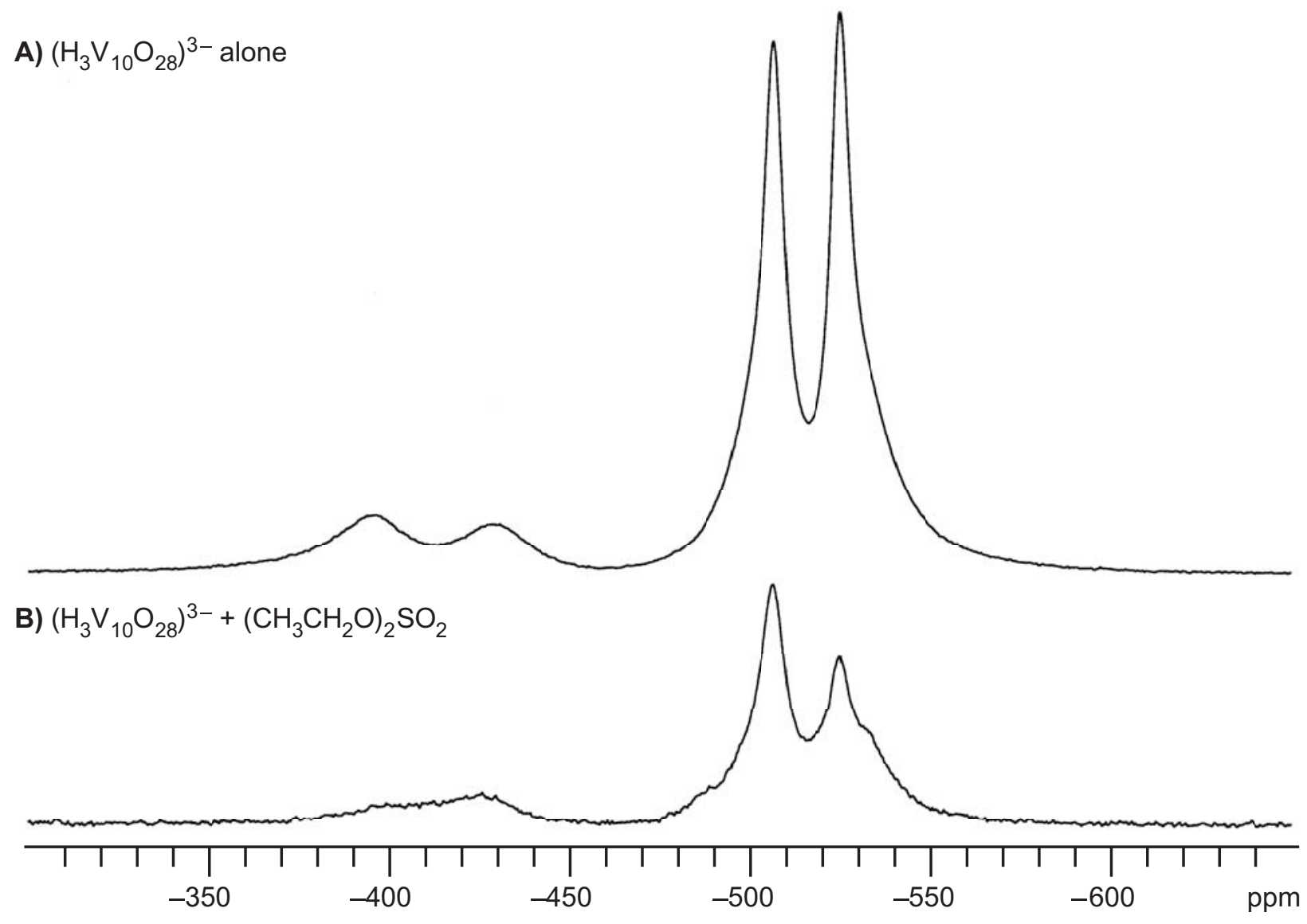

Figure S6. ${ }^{51} \mathrm{~V}$ NMR spectra of $50 \mathrm{mM}\left[\left(\mathrm{C}_{4} \mathrm{H}_{9}\right)_{4} \mathrm{~N}\right]_{3}\left(\mathrm{H}_{3} \mathrm{~V}_{10} \mathrm{O}_{28}\right)$ in $\left.\mathrm{CD}_{3} \mathrm{CN} \mathrm{A}\right)$ alone and B) with 1 equiv $\left(\mathrm{CH}_{3} \mathrm{CH}_{2} \mathrm{O}\right)_{2} \mathrm{SO}_{2}$ at $\sim 17 \mathrm{~d}$. 
A) $\left(\mathrm{V}_{10} \mathrm{O}_{26}\right)^{4-}$ alone

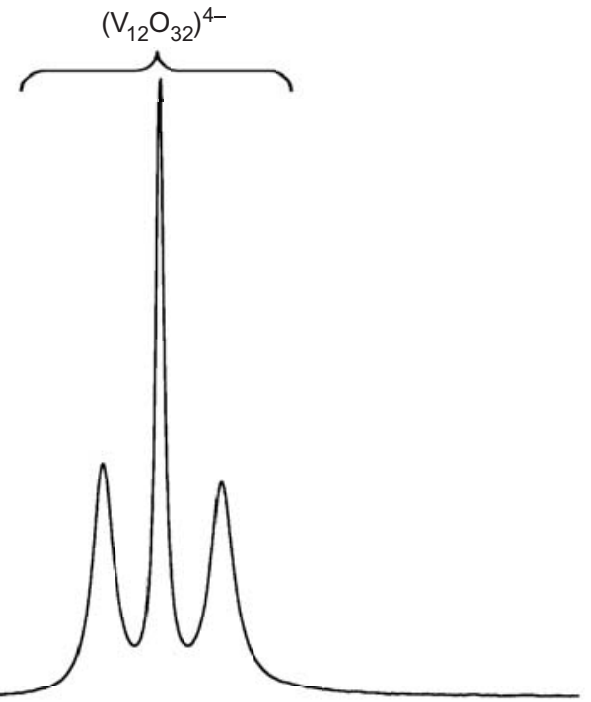

B) $\left(\mathrm{V}_{10} \mathrm{O}_{26}\right)^{4-}+\left(\mathrm{CH}_{3} \mathrm{CH}_{2} \mathrm{O}\right)_{2} \mathrm{SO}_{2}$

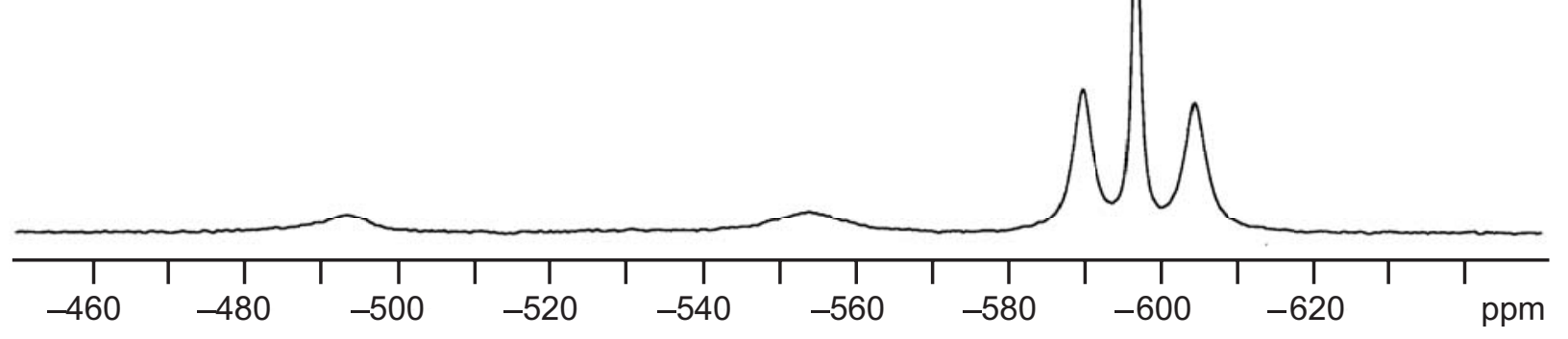

Figure S7. ${ }^{51} \mathrm{~V}$ NMR spectra of $50 \mathrm{mM}\left[\left(\mathrm{C}_{4} \mathrm{H}_{9}\right)_{4} \mathrm{~N}\right]_{4}\left(\mathrm{~V}_{10} \mathrm{O}_{26}\right)$ in $\mathrm{CD}_{3} \mathrm{CN}$ A) alone and B) with 1 equiv $\left(\mathrm{CH}_{3} \mathrm{CH}_{2} \mathrm{O}\right)_{2} \mathrm{SO}_{2}$ at $33 \mathrm{~h}$. 


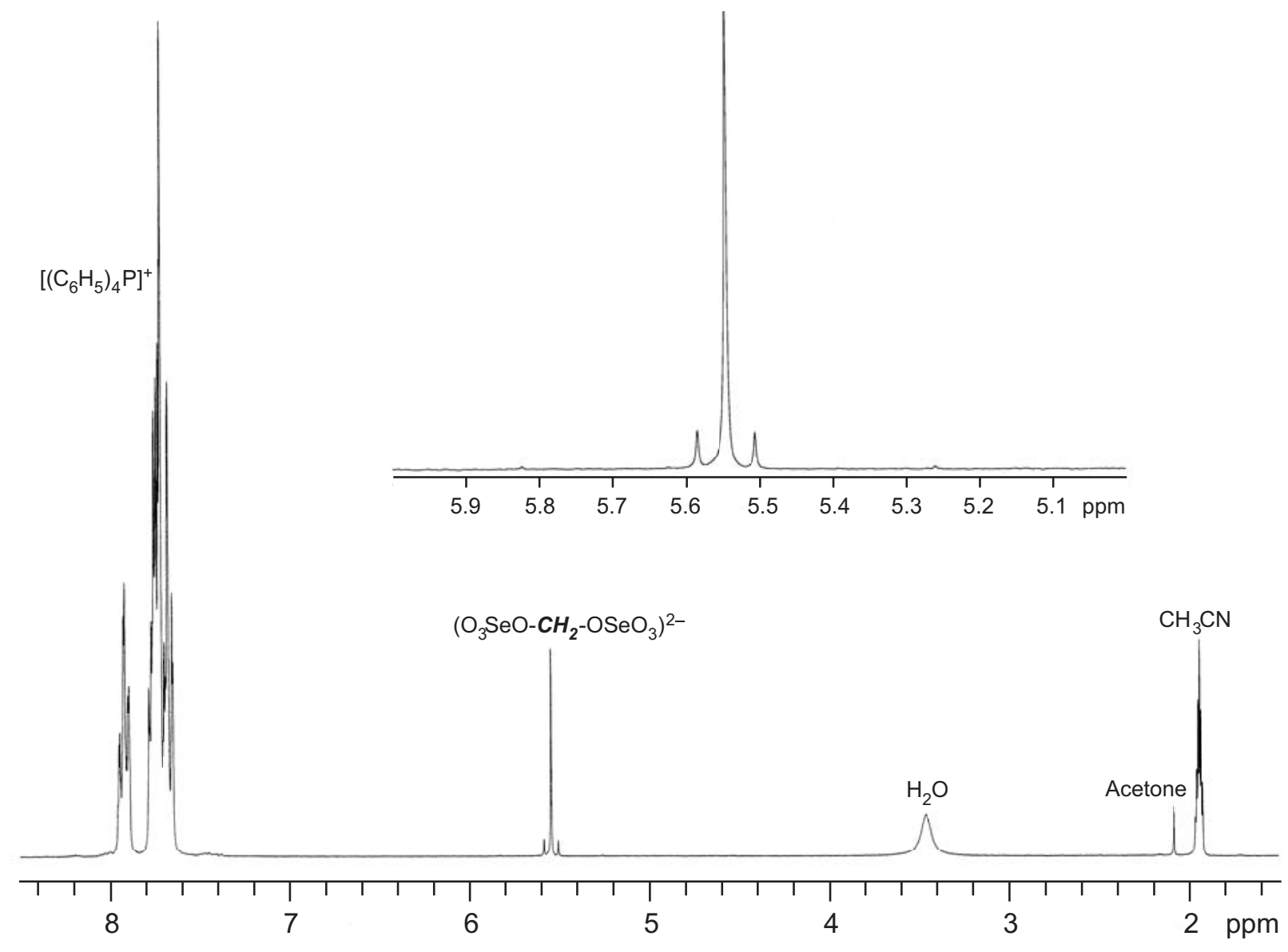

Figure S8. ${ }^{1} \mathrm{H}$ NMR spectrum of $25 \mathrm{mM}\left[\left(\mathrm{C}_{6} \mathrm{H}_{5}\right)_{4} \mathrm{P}\right]_{3}\left(\mathrm{O}_{3} \mathrm{SeOCH}_{2} \mathrm{OSeO}_{3}\right)\left(\mathrm{HSeO}_{4}\right)$ in $\mathrm{CD}_{3} \mathrm{CN}$. Inset shows splitting of the methylene group by neighboring Se atoms. Acetone is a result of the crystallization process. 


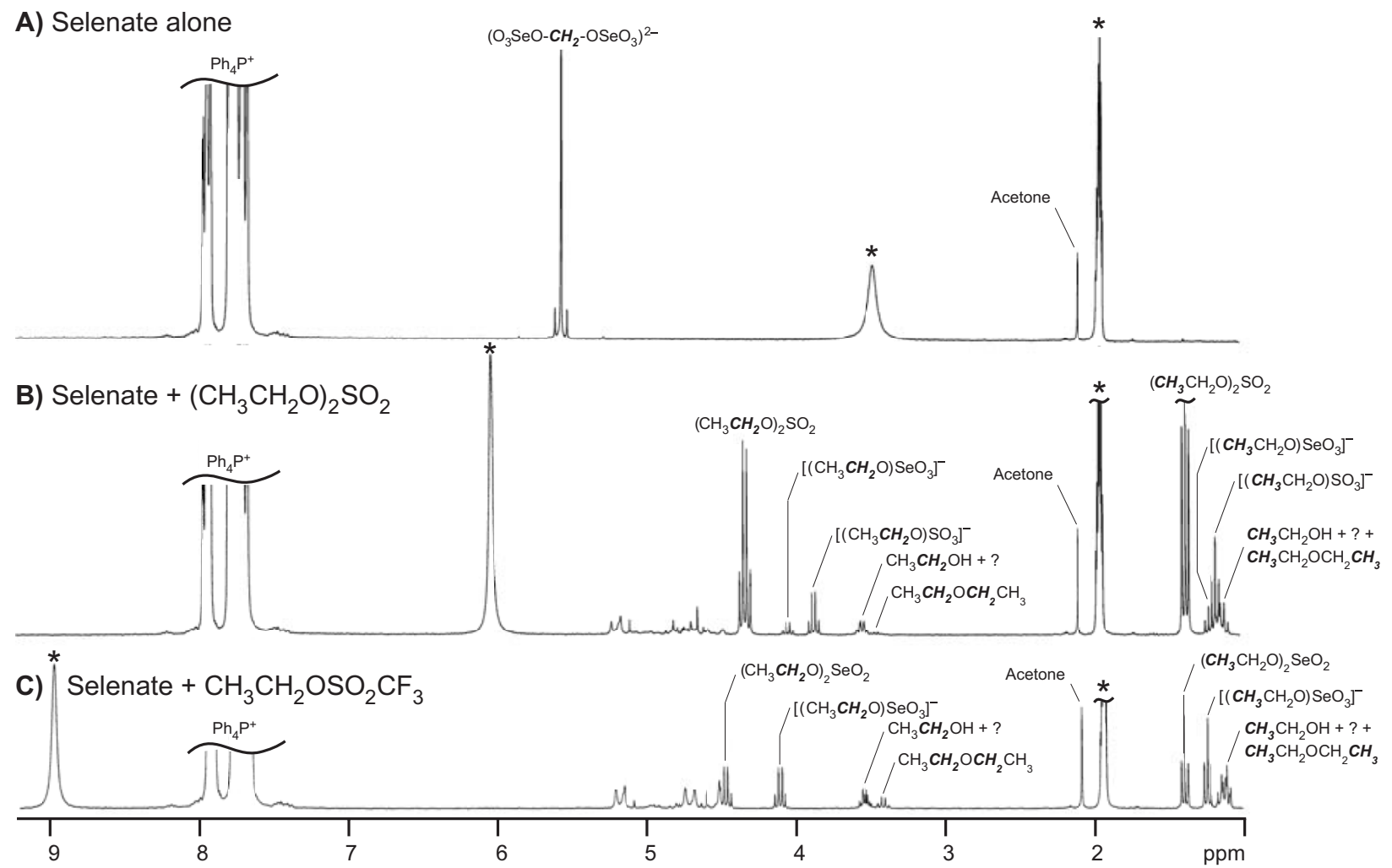

Figure S9. ${ }^{1} \mathrm{H}$ NMR spectra of $25 \mathrm{mM}\left[\left(\mathrm{C}_{6} \mathrm{H}_{5}\right)_{4} \mathrm{P}\right]_{3}\left(\mathrm{O}_{3} \mathrm{SeOCH}_{2} \mathrm{OSeO}_{3}\right)\left(\mathrm{HSeO}_{4}\right)$ in $\mathrm{CD}_{3} \mathrm{CN}$ A) alone, B) with 1 equiv $\left(\mathrm{CH}_{3} \mathrm{CH}_{2} \mathrm{O}\right)_{2} \mathrm{SO}_{2}$ at $20 \mathrm{~d}$, and $\mathrm{C}$ ) with 1 equiv $\mathrm{CH}_{3} \mathrm{CH}_{2} \mathrm{OSO}_{2} \mathrm{CF}_{3}$ at $2.5 \mathrm{~d}$. Solvent and water peaks are marked with a "*." 


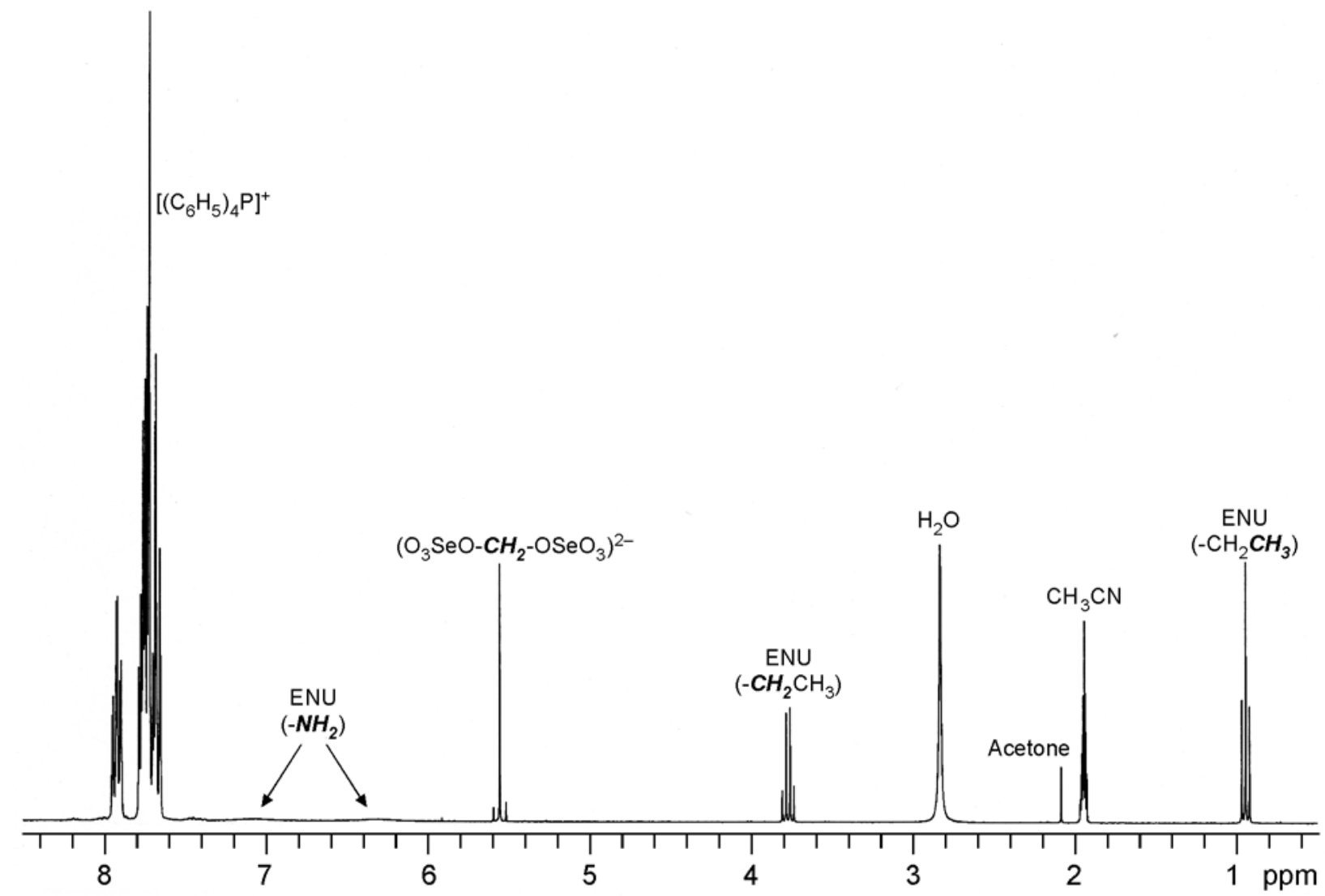

Figure S10. ${ }^{1} \mathrm{H}$ NMR spectrum of $25 \mathrm{mM}\left[\left(\mathrm{C}_{6} \mathrm{H}_{5}\right)_{4} \mathrm{P}\right]_{3}\left(\mathrm{O}_{3} \mathrm{SeOCH}_{2} \mathrm{OSeO}_{3}\right)\left(\mathrm{HSeO}_{4}\right)$ with 1 equiv $N$-ethyl- $N$-nitrosourea in $\mathrm{CD}_{3} \mathrm{CN} 2.5 \mathrm{~d}$. 
A) Selenate alone

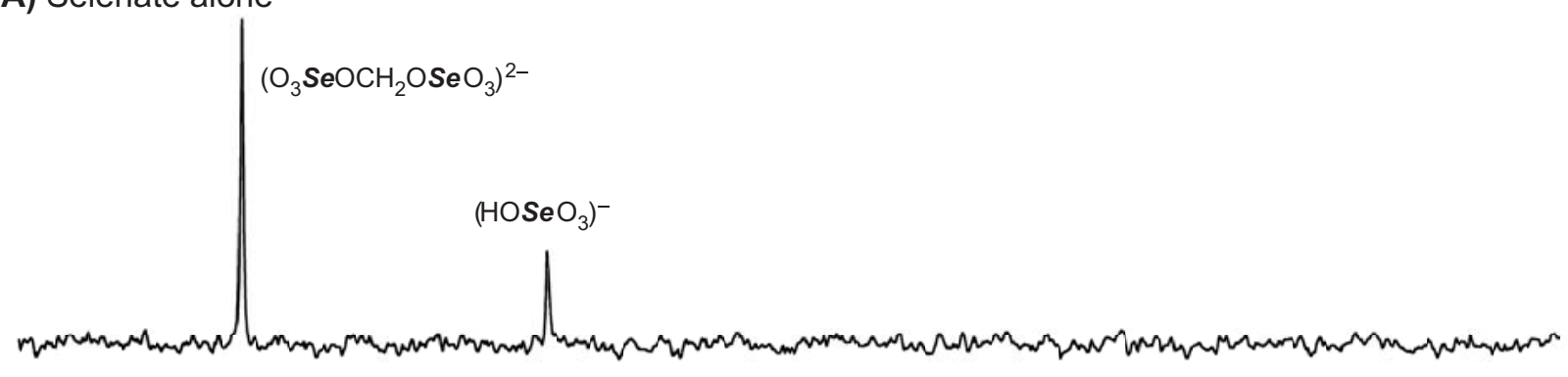

B) Selenate $+\left(\mathrm{CH}_{3} \mathrm{CH}_{2} \mathrm{O}\right)_{2} \mathrm{SO}_{2}$

$\left(\mathrm{H}_{n} \mathrm{SeO}_{4}\right)^{(2-n)-}$

C) Selenate $+\mathrm{CH}_{3} \mathrm{CH}_{2} \mathrm{OSO}_{2} \mathrm{CF}_{3}$

$\left(\mathrm{H}_{n} \mathrm{SeO}_{4}\right)^{(2-n)-}$

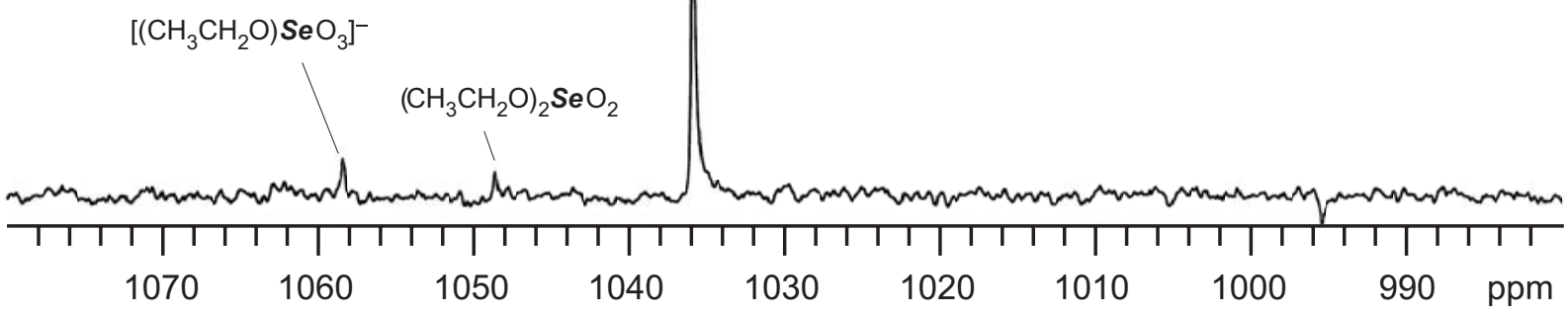

Figure S11. ${ }^{77} \mathrm{Se} \mathrm{NMR}$ spectra (proton decoupled) of $25 \mathrm{mM}\left[\left(\mathrm{C}_{6} \mathrm{H}_{5}\right)_{4} \mathrm{P}\right]_{3}\left(\mathrm{O}_{3} \mathrm{SeOCH}_{2} \mathrm{OSeO}_{3}\right)$ $\left(\mathrm{HSeO}_{4}\right)$ in $\left.\mathrm{CD}_{3} \mathrm{CN} \mathrm{A}\right)$ alone, B) with 1 equiv $\left(\mathrm{CH}_{3} \mathrm{CH}_{2} \mathrm{O}\right)_{2} \mathrm{SO}_{2}$ at $20 \mathrm{~d}$, and $\left.\mathrm{C}\right)$ with 1 equiv $\mathrm{CH}_{3} \mathrm{CH}_{2} \mathrm{OSO}_{2} \mathrm{CF}_{3}$ at $2.5 \mathrm{~d}$. 


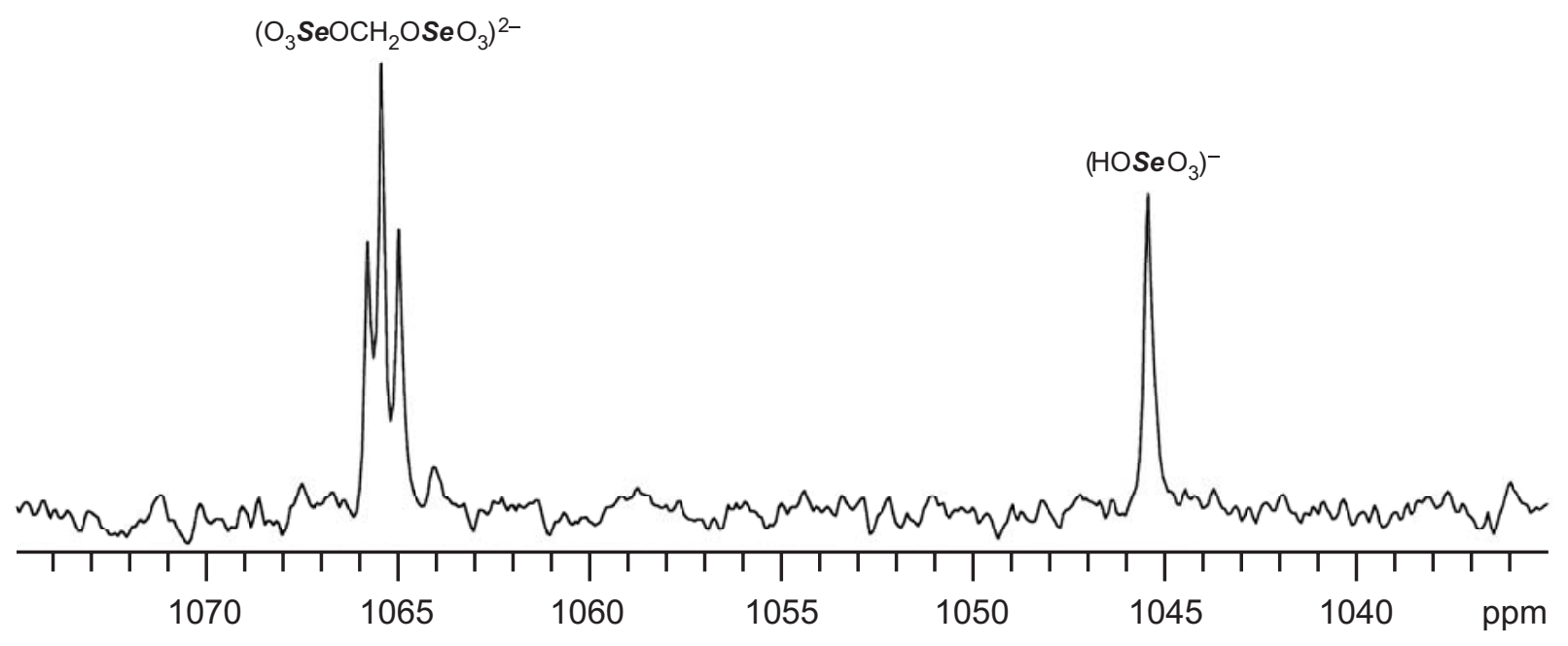

Figure S12. ${ }^{77} \mathrm{Se} N M R$ spectrum (proton coupled) of $25 \mathrm{mM}\left[\left(\mathrm{C}_{6} \mathrm{H}_{5}\right)_{4} \mathrm{P}\right]_{3}\left(\mathrm{O}_{3} \mathrm{SeOCH}_{2} \mathrm{OSeO}_{3}\right)$ $\left(\mathrm{HSeO}_{4}\right)$ in $\mathrm{CD}_{3} \mathrm{CN}$. 
A) $\left(\mathrm{CH}_{3} \mathrm{CH}_{2} \mathrm{O}\right)_{3} \mathrm{PO}$

$\left(\mathrm{CH}_{3} \mathrm{CH}_{2} \mathrm{O}\right)_{3} \mathrm{PO}$

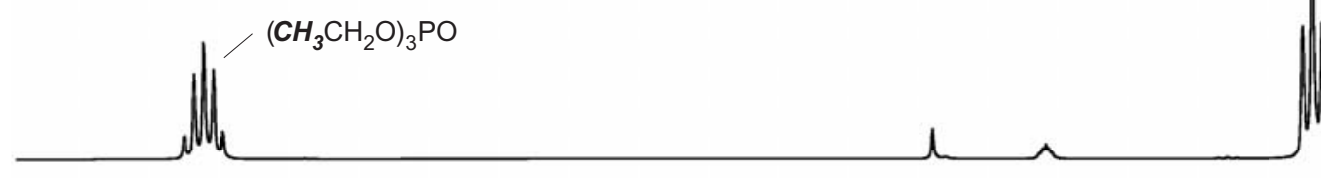

B) $\left(\mathrm{CH}_{3} \mathrm{CH}_{2} \mathrm{O}\right)_{2} \mathrm{POOH}$

$\left.\mathrm{CH}_{3} \mathrm{CH}_{2} \mathrm{O}\right)_{2} \mathrm{POOH}$

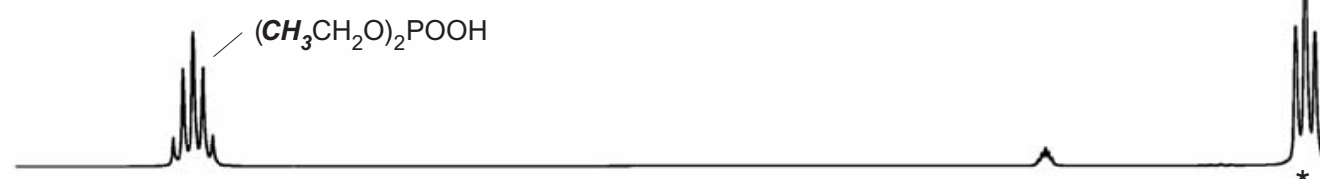

C) $\left(\mathrm{CH}_{3} \mathrm{CH}_{2} \mathrm{O}\right)_{2} \mathrm{POOH}+$ DIPEA

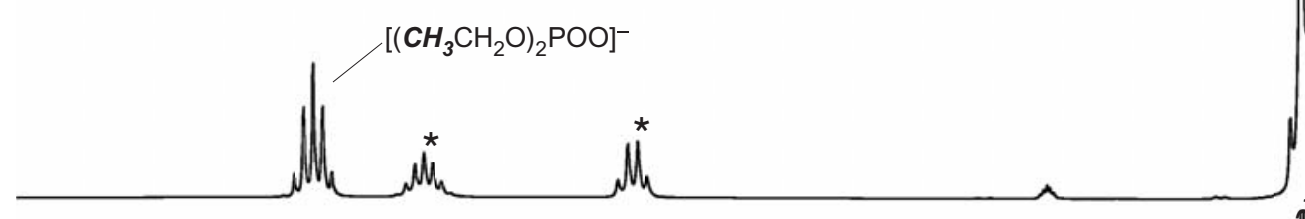

D) $\left(\mathrm{CH}_{3} \mathrm{CH}_{2} \mathrm{O}\right)_{2} \mathrm{POOH}+\mathrm{DIPEA}+\mathrm{CH}_{3} \mathrm{CH}_{2} \mathrm{I}$

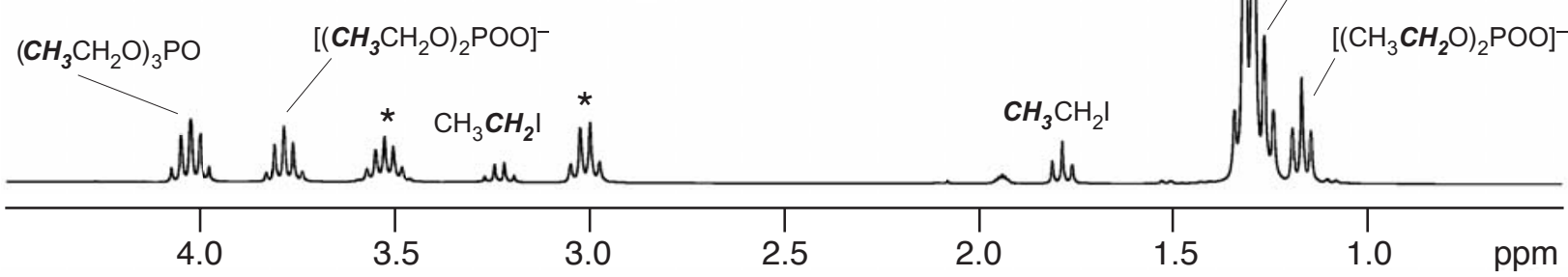

Figure S13. ${ }^{1} \mathrm{H}$ NMR spectra of phosphate controls $\left(200 \mathrm{mM}\right.$ each) in $\mathrm{CD}_{3} \mathrm{CN}$ : A) $\left(\mathrm{CH}_{3} \mathrm{CH}_{2} \mathrm{O}\right)_{3} \mathrm{PO}$, B) $\left.\left(\mathrm{CH}_{3} \mathrm{CH}_{2} \mathrm{O}\right)_{2} \mathrm{POOH}, \mathrm{C}\right)\left(\mathrm{CH}_{3} \mathrm{CH}_{2} \mathrm{O}\right)_{2} \mathrm{POOH}+$ DIPEA (1:1), and D) $\left(\mathrm{CH}_{3} \mathrm{CH}_{2} \mathrm{O}\right)_{2} \mathrm{POOH}+\mathrm{DIPEA}+\mathrm{CH}_{3} \mathrm{CH}_{2} \mathrm{I}(1: 1: 1)$ at 4 weeks. 
A) $\left(\mathrm{CH}_{3} \mathrm{CH}_{2} \mathrm{O}\right)_{3} \mathrm{PO}$

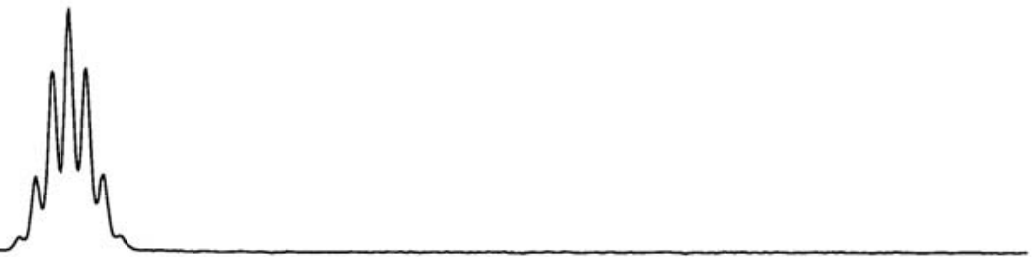

B) $\left(\mathrm{CH}_{3} \mathrm{CH}_{2} \mathrm{O}\right)_{2} \mathrm{POOH}$

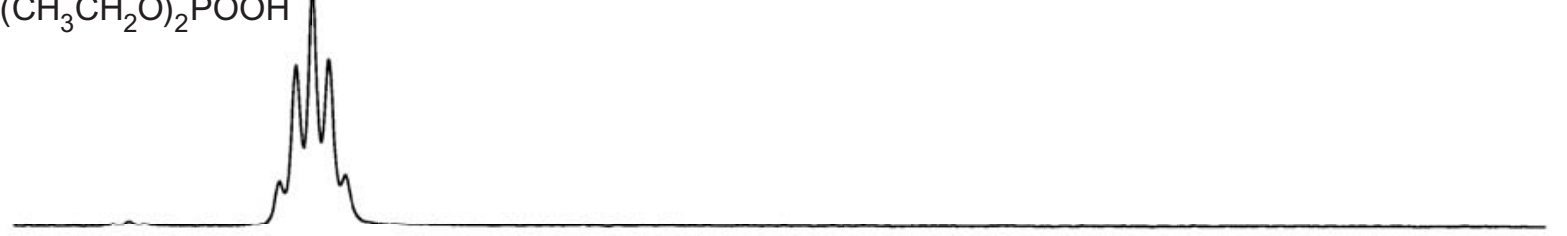

C) $\left(\mathrm{CH}_{3} \mathrm{CH}_{2} \mathrm{O}\right)_{2} \mathrm{POOH}+$ DIPEA

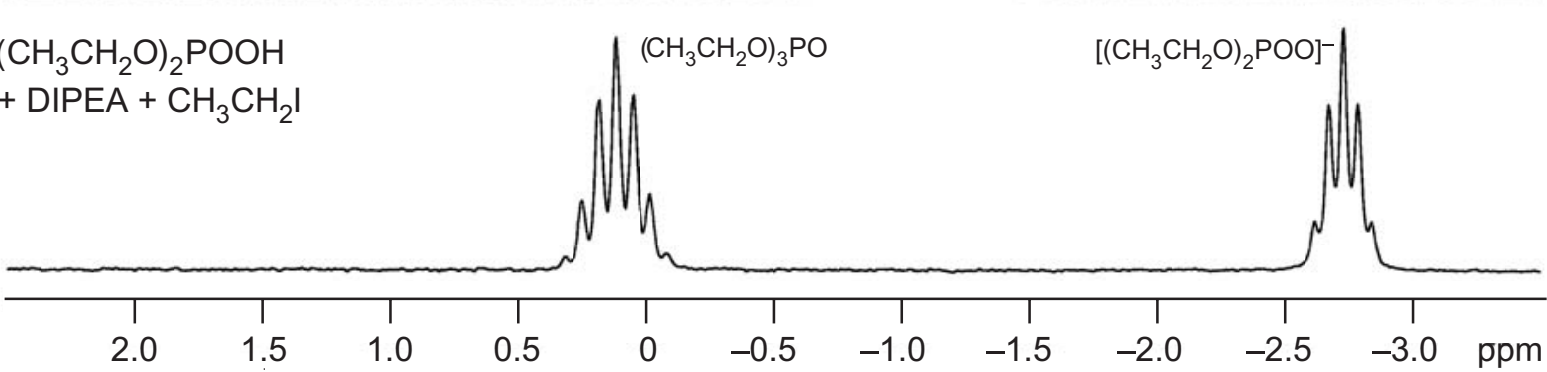

Figure S14. ${ }^{31} \mathrm{P}$ NMR spectra of phosphate controls (200 $\mathrm{mM}$ each) in $\mathrm{CD}_{3} \mathrm{CN}$ : A) $\left(\mathrm{CH}_{3} \mathrm{CH}_{2} \mathrm{O}\right)_{3} \mathrm{PO}$, B $\left.)\left(\mathrm{CH}_{3} \mathrm{CH}_{2} \mathrm{O}\right)_{2} \mathrm{POOH}, \mathrm{C}\right)\left(\mathrm{CH}_{3} \mathrm{CH}_{2} \mathrm{O}\right)_{2} \mathrm{POOH}+$ DIPEA (1:1), and D) $\left(\mathrm{CH}_{3} \mathrm{CH}_{2} \mathrm{O}\right)_{2} \mathrm{POOH}+$ DIPEA $+\mathrm{CH}_{3} \mathrm{CH}_{2} \mathrm{I}(1: 1: 1)$ at 4 weeks. 
Section S1. Detailed explanation of NMR peak assignments for phosphate alkylation products

The three ethyl groups of $\left(\mathrm{CH}_{3} \mathrm{CH}_{2} \mathrm{O}\right)_{3} \mathrm{PO}$ yielded a septet in the ${ }^{31} \mathrm{P}$ NMR spectrum at $0.28 \mathrm{ppm}$ (Figure S11A). Both $\left(\mathrm{CH}_{3} \mathrm{CH}_{2} \mathrm{O}\right)_{2} \mathrm{POOH}$ and $\left(\mathrm{CH}_{3} \mathrm{CH}_{2} \mathrm{O}\right)_{2} \mathrm{POOH}$ with the added base DIPEA (“ $\left[\left(\mathrm{CH}_{3} \mathrm{CH}_{2} \mathrm{O}\right)_{2} \mathrm{PO}_{2}\right]^{-”)}$ ) produced a quintet pattern at $1.45 \mathrm{ppm}$ and $-0.89 \mathrm{ppm}$, respectively (Figures S11B and S11C). This upfield shift was opposite of the observed behavior for the deprotonation of $\left(\mathrm{H}_{2} \mathrm{PO}_{4}\right)^{-}$. The singlet of $\left[\left(\mathrm{C}_{4} \mathrm{H}_{9}\right)_{4} \mathrm{~N}\right]\left(\mathrm{H}_{2} \mathrm{PO}_{4}\right)$ at $4.11 \mathrm{ppm}$ shifted downfield to $5.76 \mathrm{ppm}$ when deprotonated by $\mathrm{NaH}$ (data not shown).

In addition to ${ }^{31} \mathrm{P}$ NMR spectra, ${ }^{1} \mathrm{H}$ NMR data also provided insight on the nature of phosphoester species formed upon alkylation. The chemical shifts of the ethyl quartets in the ${ }^{1} \mathrm{H}$ NMR spectra were an indication of the overall charge of the phosphate. Neutral phosphates such as $\left(\mathrm{CH}_{3} \mathrm{CH}_{2} \mathrm{O}\right)_{3} \mathrm{PO}$ and $\left(\mathrm{CH}_{3} \mathrm{CH}_{2} \mathrm{O}\right)_{2} \mathrm{POOH}$ yielded nearly identical chemical shift values for the ethyl group (Figures 10A and 10B). When $\left(\mathrm{CH}_{3} \mathrm{CH}_{2} \mathrm{O}\right)_{2} \mathrm{POOH}$ was deprotonated by addition of DIPEA, the ethyl resonances shifted upfield to $1.15 \mathrm{ppm}$ (triplet) and $3.77 \mathrm{ppm}$ (quintet) (Figure 10C). Thus, ${ }^{1} \mathrm{H}$ NMR chemical shift values were used to distinguish between neutral and negatively charged phosphate species.

The ${ }^{31} \mathrm{P}$ NMR spectrum of a 1:1 reaction between $\left[\left(\mathrm{C}_{4} \mathrm{H}_{9}\right)_{4} \mathrm{~N}\right]\left(\mathrm{H}_{2} \mathrm{PO}_{4}\right)$ and $\mathrm{CH}_{3} \mathrm{CH}_{2} \mathrm{I}$ showed two products (Figure 5A). The first and major product exhibited a triplet phosphate resonance at $2.58 \mathrm{ppm}$ in the ${ }^{31} \mathrm{P}$ NMR spectrum and ethyl peaks at $1.15 \mathrm{ppm}$ (triplet) and $3.75 \mathrm{ppm}$ (quintet) in the ${ }^{1} \mathrm{H}$ NMR spectrum (Figure 4A). These data suggest the initial product formed contained one ethyl group and was negatively charged: $\left(\mathrm{CH}_{3} \mathrm{CH}_{2} \mathrm{O}\right) \mathrm{P}(\mathrm{OH}) \mathrm{O}_{2}^{-}$. The second and minor product displayed a quintet phosphate signal downfield at $3.32 \mathrm{ppm}$ in the ${ }^{31} \mathrm{P}$ NMR spectrum and ethyl resonances at $1.15 \mathrm{ppm}$ (triplet) and $3.75 \mathrm{ppm}$ (quintet) in the ${ }^{1} \mathrm{H}$ NMR spectrum, which overlap the ethyl resonances of the first product. These data indicate the second product has two ethyl group and is charged: $\left(\mathrm{CH}_{3} \mathrm{CH}_{2} \mathrm{O}\right)_{2} \mathrm{P}(\mathrm{OH}) \mathrm{O}^{-}$. A third product was visible in the ${ }^{1} \mathrm{H}$ NMR spectrum (multiplet at $4.03 \mathrm{ppm}$ ) but was not observed by ${ }^{31} \mathrm{P}$ NMR spectroscopy. Based on the ${ }^{1} \mathrm{H}$ NMR data this third product is a neutral phosphate.

The base-assisted alkylation of $\left[\left(\mathrm{C}_{4} \mathrm{H}_{9}\right)_{4} \mathrm{~N}\right]\left(\mathrm{H}_{2} \mathrm{PO}_{4}\right)$ yielded three products, as determined by ${ }^{31} \mathrm{P}$ NMR spectroscopy. The first product showed ethyl resonances at $1.15 \mathrm{ppm}$ (triplet) and $3.75 \mathrm{ppm}$ (quintet) in the ${ }^{1} \mathrm{H}$ NMR spectrum (Figure 4B) and a triplet phosphate resonance was observed at 2.36 ppm in the ${ }^{31} \mathrm{P}$ NMR spectrum (Figure 5B). These data indicate a negatively charged species with one ethyl group: $\left(\mathrm{CH}_{3} \mathrm{CH}_{2} \mathrm{O}\right) \mathrm{P}(\mathrm{OH}) \mathrm{O}_{2}^{-}$. The second product yielded ethyl resonances at $1.15 \mathrm{ppm}$ (triplet) and $3.75 \mathrm{ppm}$ (quintet) in the ${ }^{1} \mathrm{H}$ NMR spectrum, which overlapped with the first product, and a quintet phosphate signal at $1.03 \mathrm{ppm}$ in the ${ }^{31} \mathrm{P}$ NMR spectrum. These data suggest a charged species with two ethyl groups: $\left[\left(\mathrm{CH}_{3} \mathrm{CH}_{2} \mathrm{O}\right)_{2} \mathrm{PO}_{2}\right]^{-}$. The final, minor product had a septet phosphate resonance in the ${ }^{31} \mathrm{P}$ NMR spectrum, and the corresponding ethyl peaks (obscured triplet, quintet at $4.03 \mathrm{ppm}$ ) in the ${ }^{1} \mathrm{H}$ NMR. This final product contained three ethyl groups and was neutral: $\left(\mathrm{CH}_{3} \mathrm{CH}_{2} \mathrm{O}\right)_{3} \mathrm{PO}$. 
Table S1. Experimental procedures for X-ray crystal structure determination of $\left[\left(\mathrm{C}_{6} \mathrm{H}_{5}\right)_{4} \mathrm{P}\right]_{3}\left(\mathrm{O}_{3} \mathrm{SeOCH}_{2} \mathrm{OSeO}_{3}\right)\left(\mathrm{HSeO}_{4}\right)$

\section{DATA COLLECTION}

A colorless plate of $\mathrm{CH}_{2} \mathrm{O}_{8} \mathrm{Se}_{2}, \mathrm{O}_{4} \mathrm{Se}, 3\left(\mathrm{C}_{24} \mathrm{H}_{20} \mathrm{P}\right)$ having approximate dimensions of 0.43 $\mathrm{mm} \times 0.40 \mathrm{~mm} \times 0.23 \mathrm{~mm}$ was mounted on a glass fiber in a random orientation. Preliminary examination and data collection were performed $\mathrm{Mo} \mathrm{K}_{\mathrm{a}}$ radiation $(\lambda=0.71073 \AA)$ on a Nonius KappaCCD equipped with a graphite crystal, incident beam monochromator.

Cell constants for data collection were obtained from least-squares refinement, using the setting angles of 48645 reflections in the range $2^{\circ}<\theta<27^{\circ}$. The triclinic cell parameters and calculated volume are: $a=11.2388(6) \AA, b=14.2154(10) \AA, c=22.1303(11) \AA, \alpha=79.479(4)^{\circ}$, $\beta=82.355(3)^{\circ}, \gamma=67.324(4)^{\circ}, V=3199.8(3) \AA^{3}$. For $Z=2$ and F.W. $=1461.10$ the calculated density is $1.52 \mathrm{~g} / \mathrm{cm}^{3}$. The refined mosaicity from DENZO/SCALEPACK (ref 1) was $0.48^{\circ}$ indicating good crystal quality. The space group was determined by the program XPREP (ref 2). There were no systematic absences; the space group was determined to be $\mathrm{P}$-1(\#2).

The data were collected at a temperature of $150(1) \mathrm{K}$. Data were collected to a maximum $2 \theta$ of $55.8^{\circ}$.

\section{DATA REDUCTION}

A total of 48645 reflections were collected, of which 11244 were unique. Frames were integrated with DENZO-SMN (ref 1).

Lorentz and polarization corrections were applied to the data. The linear absorption coefficient is $18.4 / \mathrm{cm}$ for $\mathrm{Mo} \mathrm{K}_{\mathrm{a}}$ radiation. An empirical absorption correction using SCALEPACK (ref 1) was applied. Transmission coefficients ranged from 0.630 to 0.661. Intensities of equivalent reflections were averaged. The agreement factor for the averaging was $4.3 \%$ based on intensity.

\section{STRUCTURE SOLUTION AND REFINEMENT}

The structure was solved by direct methods using SIR2002 (ref 3). The remaining atoms were located in succeeding difference Fourier syntheses. Hydrogen atoms were included in the refinement but restrained to ride on the atom to which they are bonded. The structure was refined in full-matrix least-squares where the function minimized was $\Sigma w\left(|F o|^{2}-\mid \mathrm{Fcl}^{2}\right)^{2}$ and the weight $\mathrm{w}$ is defined as $1 /\left[\sigma^{2}\left(\mathrm{~F}_{\mathrm{o}}{ }^{2}\right)+(0.0984 \mathrm{P})^{2}+10.1954 \mathrm{P}\right]$ where $\mathrm{P}=\left(\mathrm{F}_{\mathrm{o}}{ }^{2}+2 \mathrm{~F}_{\mathrm{c}}{ }^{2}\right) / 3$. Scattering factors were taken from the "International Tables for Crystallography" (ref 4). 11244 reflections were used in the refinements. However, only the 8741 reflections with $F_{o}{ }^{2}>2 \sigma\left(F_{o}{ }^{2}\right)$ were used in, calculating R1. The final cycle of refinement included 839 variable parameters and converged (largest parameter shift was $<0.01$ times its su) with unweighted and weighted agreement factors of:

$$
\begin{gathered}
\mathrm{R} 1=\Sigma \mid \mathrm{F}_{\mathrm{o}}-\mathrm{F}_{\mathrm{c}} \mathrm{l} / \Sigma \mathrm{F}_{\mathrm{o}}=0.068 \\
\mathrm{R} 2=\operatorname{SQRT}\left(\sum \mathrm{W}\left(\mathrm{F}_{\mathrm{o}}{ }^{2}-\mathrm{F}_{\mathrm{c}}{ }^{2}\right)^{2} / \Sigma \mathrm{W}\left(\mathrm{F}_{\mathrm{o}}{ }^{2}\right)^{2}\right)=0.179
\end{gathered}
$$

The standard deviation of an observation of unit weight was 1.06. The highest peak in the final difference Fourier had a height of $3.13 \mathrm{e} / \AA^{3}$. The minimum negative peak had a height of -1.58 $\mathrm{e} / \AA^{3}$. 
Table S1. (Continued)

Refinement was performed on a LINUX PC using SHELX-97 (ref 5). Crystallographic drawings were done using programs ORTEP (ref 6) and PLUTON (ref 7).

\section{REFERENCES}

(1) Z. Otwinowski and W. Minor, Methods Enzymol., 276, 307 (1997).

(2) Bruker, XPREP in SHELXTL version 6.12, Bruker AXS Inc., Madison, Wisconson, USE, (2002)

(3) M. C. Burla, M. Camalli, B. Carrozzini, G. L. Cascarano, C. Giacovazzo, G. Polidori, and R. Spagna. , J. Appl. Cryst., 36, 1103 (2003)

(4) "International Tables for Crystallography", Vol. C, Kluwer Academic Publishers, Utrecht, The Netherlands, (1992), Tables 4.2.6.8 and 6.1.1.4

(5) G. M. Sheldrick, SHELXL97. A Program for Crystal Structure Refinement. Univ. of Gottingen, Germany, (1997).

(6) C. K. Johnson, ORTEPII, Report ORNL-5138, Oak Ridge National Laboratory, Tennessee, USA (1976)

(7) A. L. Spek, PLUTON. Molecular Graphics Program. Univ. of Ultrecht, The Netherlands (1991) 
Table S2. Crystal data and data collection parameters for $\left[\left(\mathrm{C}_{6} \mathrm{H}_{5}\right)_{4} \mathrm{P}\right]_{3}\left(\mathrm{O}_{3} \mathrm{SeOCH}_{2} \mathrm{OSeO}_{3}\right)\left(\mathrm{HSeO}_{4}\right)$

Formula

Formula weight

Space group

Color of crystal

Dimensions of crystal

$a$

$b$

$c$

Z

Linear absorption coefficient

Range of transmission factors

Temperature

Wavelength of radiation

$2 \theta$ range

Number of data

Unique data

Data used in refinement

Data with $I>2.0 \sigma(I)$

Cut-off

Number of parameters refined

$R\left(F_{\mathrm{o}}\right)^{\mathrm{a}}$

$R_{\mathrm{w}}\left(F_{\mathrm{o}}^{2}\right)^{\mathrm{b}}$

Goodness of fit

Calculated density
$\mathrm{C}_{73} \mathrm{H}_{62} \mathrm{O}_{12} \mathrm{P}_{3} \mathrm{Se}_{3}$

1461.10

P-1 (No. 2)

colorless

$0.43 \mathrm{~mm} \times 0.40 \mathrm{~mm} \times 0.23 \mathrm{~mm}$

11.2388(6) $\AA$

14.2154(10) $\AA$

22.1303(11) ̊

2

$1.842 \mathrm{~mm}^{-1}$

0.63 to 0.66

150. K

$\operatorname{Mo~K}_{\alpha}(0.71073 \AA$ A $)$

$4.12^{\circ}$ to $55.81^{\circ}$

48645

11244

11244

8741

$F_{\mathrm{o}}^{2}>2.0 \sigma\left(F_{\mathrm{o}}{ }^{2}\right)$

839

0.068

0.179

1.057

$1.516 \mathrm{~g} \mathrm{~cm}^{-1}$

${ }^{\mathrm{a}} R=\Sigma\left\|F_{\mathrm{o}}|-| F_{\mathrm{c}}\right\| / \Sigma\left|F_{\mathrm{o}}\right|$ for $F_{\mathrm{o}}{ }^{2}>2.0 \sigma\left(F_{\mathrm{o}}{ }^{2}\right)$

${ }^{\mathrm{b}} R_{\mathrm{w}}=\left[\Sigma \mathrm{w}\left(\left|F_{\mathrm{o}}{ }^{2}\right|-\left|F_{\mathrm{c}}{ }^{2}\right|\right)^{2} / \Sigma \mathrm{w}\left|F_{\mathrm{o}}{ }^{2}\right|^{2}\right]^{1 / 2}$ 
Table S3. Positional parameters for $\left[\left(\mathrm{C}_{6} \mathrm{H}_{5}\right)_{4} \mathrm{P}\right]_{3}\left(\mathrm{O}_{3} \mathrm{SeOCH}_{2} \mathrm{OSeO}_{3}\right)\left(\mathrm{HSeO}_{4}\right)$

\begin{tabular}{|c|c|c|c|c|}
\hline Atom & $\mathrm{X}$ & $\mathrm{y}$ & $\mathrm{Z}$ & $\mathrm{U}\left(\AA^{2}\right)$ \\
\hline $\operatorname{Se}(1)$ & $-0.24507(7)$ & $0.19916(5)$ & $0.18217(3)$ & $0.0478(2)$ \\
\hline $\mathrm{Se}(2)$ & $0.21849(5)$ & $0.16902(4)$ & $0.15699(2)$ & $0.03150(19)$ \\
\hline $\operatorname{Se}(3)$ & $0.20180(6)$ & $0.47999(5)$ & $0.49325(3)$ & $0.0464(2)$ \\
\hline$P(1)$ & $0.25239(12)$ & $-0.24298(10)$ & $0.10865(6)$ & $0.0229(4)$ \\
\hline $\mathrm{P}(2)$ & $-0.22623(12)$ & $0.59509(9)$ & $0.22186(6)$ & $0.0222(4)$ \\
\hline $\mathrm{P}(3)$ & $0.22275(12)$ & $0.08193(9)$ & $0.44494(6)$ & $0.0219(4)$ \\
\hline $\mathrm{O}(11)$ & $-0.2420(8)$ & $0.0962(5)$ & $0.2288(4)$ & $0.118(4)$ \\
\hline $\mathrm{O}(12)$ & $-0.3392(8)$ & $0.2969(4)$ & $0.2141(3)$ & $0.100(3)$ \\
\hline $\mathrm{O}(13)$ & $-0.2547(8)$ & $0.2123(8)$ & $0.1120(4)$ & $0.176(5)$ \\
\hline $\mathrm{O}(14)$ & $-0.1101(8)$ & $0.2158(9)$ & $0.1923(4)$ & $0.162(6)$ \\
\hline $\mathrm{O}(21)$ & $0.2491(5)$ & $0.0787(3)$ & $0.1164(2)$ & $0.0536(17)$ \\
\hline $\mathrm{O}(24)$ & $0.0993(7)$ & $0.1552(7)$ & $0.2175(3)$ & $0.117(4)$ \\
\hline $\mathrm{O}(31)$ & $0.3408(7)$ & $0.4125(6)$ & $0.5130(4)$ & $0.123(3)$ \\
\hline $\mathrm{O}(32)$ & $0.1424(5)$ & $0.4062(3)$ & $0.4638(2)$ & $0.062(2)$ \\
\hline $\mathrm{O}(33)$ & $0.1046(6)$ & $0.5174(6)$ & $0.5536(3)$ & $0.090(3)$ \\
\hline $\mathrm{O}(34)$ & $0.1955(6)$ & $0.5791(5)$ & $0.4419(3)$ & $0.076(2)$ \\
\hline $\mathrm{O}(22 \mathrm{~A})$ & $0.2738(19)$ & $0.2521(11)$ & $0.1216(8)$ & $0.072(8)$ \\
\hline $\mathrm{O}(22 \mathrm{~B})$ & $0.1445(7)$ & $0.2844(5)$ & $0.1186(3)$ & $0.050(3)$ \\
\hline $\mathrm{O}(23 \mathrm{~A})$ & $0.2670(13)$ & $0.1109(11)$ & $0.2271(6)$ & $0.046(5)$ \\
\hline$O(23 B)$ & $0.3266(8)$ & $0.1655(7)$ & $0.1963(4)$ & $0.075(4)$ \\
\hline$C(1 B)$ & $-0.0054(7)$ & $0.1583(16)$ & $0.2009(6)$ & $0.235(11)$ \\
\hline $\mathrm{C}(111)$ & $0.3144(5)$ & $-0.3791(4)$ & $0.1052(2)$ & $0.0267(17)$ \\
\hline C(112) & $0.2322(6)$ & $-0.4339(4)$ & $0.1215(2)$ & $0.0334(19)$ \\
\hline C(113) & $0.2822(6)$ & $-0.5400(4)$ & $0.1212(3)$ & $0.039(2)$ \\
\hline $\mathrm{C}(114)$ & $0.4124(6)$ & $-0.5903(4)$ & $0.1053(3)$ & $0.042(2)$ \\
\hline $\mathrm{C}(115)$ & $0.4927(6)$ & $-0.5359(4)$ & $0.0886(3)$ & $0.042(2)$ \\
\hline $\mathrm{C}(116)$ & $0.4435(5)$ & $-0.4296(4)$ & $0.0884(2)$ & $0.0312(18)$ \\
\hline $\mathrm{C}(121)$ & $0.3652(5)$ & $-0.1911(4)$ & $0.0648(2)$ & $0.0248(16)$ \\
\hline$C(122)$ & $0.4481(5)$ & $-0.1641(4)$ & $0.0931(3)$ & $0.0316(18)$ \\
\hline $\mathrm{C}(123)$ & $0.5389(6)$ & $-0.1303(5)$ & $0.0581(3)$ & $0.0392(19)$ \\
\hline C(124) & $0.5489(5)$ & $-0.1249(4)$ & $-0.0050(3)$ & $0.0362(18)$ \\
\hline $\mathrm{C}(125)$ & $0.4660(5)$ & $-0.1520(4)$ & $-0.0338(3)$ & $0.0342(18)$ \\
\hline$C(126)$ & $0.3738(5)$ & $-0.1846(4)$ & $0.0009(2)$ & $0.0285(18)$ \\
\hline $\mathrm{C}(131)$ & $0.0996(5)$ & $-0.1840(4)$ & $0.0745(2)$ & $0.0244(15)$ \\
\hline $\mathrm{C}(132)$ & $0.0071(5)$ & $-0.0931(4)$ & $0.0929(2)$ & $0.0304(18)$ \\
\hline $\mathrm{C}(133)$ & $-0.1052(5)$ & $-0.0425(4)$ & $0.0623(3)$ & $0.0354(18)$ \\
\hline $\mathrm{C}(134)$ & $-0.1255(5)$ & $-0.0821(5)$ & $0.0133(3)$ & $0.0360(19)$ \\
\hline $\mathrm{C}(135)$ & $-0.0349(6)$ & $-0.1722(5)$ & $-0.0048(3)$ & $0.040(2)$ \\
\hline $\mathrm{C}(136)$ & $0.0785(6)$ & $-0.2230(5)$ & $0.0254(3)$ & $0.0368(19)$ \\
\hline $\mathrm{C}(141)$ & $0.2355(5)$ & $-0.2205(4)$ & $0.1876(2)$ & $0.0243(15)$ \\
\hline $\mathrm{C}(142)$ & $0.2142(5)$ & $-0.1224(4)$ & $0.2001(2)$ & $0.0294(18)$ \\
\hline C(143) & $0.2007(5)$ & $-0.1051(4)$ & $0.2604(2)$ & $0.0340(18)$ \\
\hline C(144) & $0.2117(5)$ & $-0.1855(4)$ & $0.3085(3)$ & $0.0343(19)$ \\
\hline $\mathrm{C}(145)$ & $0.2329(6)$ & $-0.2825(4)$ & $0.2961(2)$ & $0.0348(18)$ \\
\hline C(146) & $0.2445(5)$ & $-0.3010(4)$ & $0.2356(2)$ & $0.0288(18)$ \\
\hline $\mathrm{C}(211)$ & $-0.0699(5)$ & $0.5387(4)$ & $0.2532(2)$ & $0.0239(15)$ \\
\hline $\mathrm{C}(212)$ & $0.0228(5)$ & $0.4491(4)$ & $0.2329(2)$ & $0.0292(18)$ \\
\hline $\mathrm{C}(213)$ & $0.1375(5)$ & $0.4005(4)$ & $0.2616(2)$ & $0.0338(18)$ \\
\hline $\mathrm{C}(214)$ & $0.1624(5)$ & $0.4398(4)$ & $0.3090(3)$ & $0.0324(18)$ \\
\hline$C(215)$ & $0.0720(6)$ & $0.5292(4)$ & $0.3284(3)$ & $0.0355(19)$ \\
\hline
\end{tabular}


Table S3. (Continued)

\begin{tabular}{|c|c|c|c|c|}
\hline Atom & $\mathrm{X}$ & $\mathrm{y}$ & Z & $\mathrm{U}\left(\AA^{2}\right)$ \\
\hline $\mathrm{C}(221)$ & $-0.2894(5)$ & $0.7315(4)$ & $0.2233(2)$ & $0.0237(15)$ \\
\hline$C(222)$ & $-0.2087(5)$ & $0.7880(4)$ & $0.2035(2)$ & $0.0313(18)$ \\
\hline $\mathrm{C}(223)$ & $-0.2601(6)$ & $0.8944(4)$ & $0.2021(3)$ & $0.0344(19)$ \\
\hline $\mathrm{C}(224)$ & $-0.3891(6)$ & $0.9440(4)$ & $0.2197(2)$ & $0.035(2)$ \\
\hline $\mathrm{C}(225)$ & $-0.4673(6)$ & $0.8886(4)$ & $0.2396(3)$ & $0.0361(18)$ \\
\hline$C(226)$ & $-0.4177(5)$ & $0.7818(4)$ & $0.2420(2)$ & $0.0280(18)$ \\
\hline $\mathrm{C}(231)$ & $-0.3356(5)$ & $0.5435(4)$ & $0.2696(2)$ & $0.0278(16)$ \\
\hline$C(232)$ & $-0.3400(5)$ & $0.5403(4)$ & $0.3330(3)$ & $0.0317(18)$ \\
\hline $\mathrm{C}(233)$ & $-0.4275(6)$ & $0.5054(4)$ & $0.3718(3)$ & $0.0403(18)$ \\
\hline $\mathrm{C}(234)$ & $-0.5101(6)$ & $0.4741(5)$ & $0.3457(3)$ & $0.045(2)$ \\
\hline$C(235)$ & $-0.5058(6)$ & $0.4766(4)$ & $0.2840(3)$ & $0.043(2)$ \\
\hline$C(236)$ & $-0.4190(5)$ & $0.5118(4)$ & $0.2445(3)$ & $0.0353(18)$ \\
\hline $\mathrm{C}(241)$ & $-0.2095(5)$ & $0.5680(4)$ & $0.1446(2)$ & $0.0294(18)$ \\
\hline $\mathrm{C}(242)$ & $-0.1884(5)$ & $0.4674(4)$ & $0.1355(3)$ & $0.0378(19)$ \\
\hline $\mathrm{C}(243)$ & $-0.1648(6)$ & $0.4426(5)$ & $0.0767(3)$ & $0.049(2)$ \\
\hline $\mathrm{C}(244)$ & $-0.1630(7)$ & $0.5172(7)$ & $0.0272(3)$ & $0.063(3)$ \\
\hline$C(245)$ & $-0.1862(7)$ & $0.6169(6)$ & $0.0352(3)$ & $0.061(3)$ \\
\hline $\mathrm{C}(246)$ & $-0.2089(6)$ & $0.6428(5)$ & $0.0948(3)$ & $0.040(2)$ \\
\hline $\mathrm{C}(311)$ & $0.3372(5)$ & $0.1369(4)$ & $0.4074(2)$ & $0.0246(15)$ \\
\hline$C(312)$ & $0.3630(5)$ & $0.1388(4)$ & $0.3437(2)$ & $0.0276(18)$ \\
\hline$C(313)$ & $0.4511(5)$ & $0.1805(4)$ & $0.3135(3)$ & $0.0318(18)$ \\
\hline $\mathrm{C}(314)$ & $0.5122(5)$ & $0.2214(4)$ & $0.3465(3)$ & $0.0331(18)$ \\
\hline$C(315)$ & $0.4836(5)$ & $0.2219(4)$ & $0.4089(3)$ & $0.0341(18)$ \\
\hline$C(316)$ & $0.3957(5)$ & $0.1800(4)$ & $0.4402(2)$ & $0.0290(18)$ \\
\hline $\mathrm{C}(321)$ & $0.2864(5)$ & $-0.0554(4)$ & $0.4457(2)$ & $0.0251(15)$ \\
\hline$C(322)$ & $0.2131(5)$ & $-0.1116(4)$ & $0.4788(2)$ & $0.0316(18)$ \\
\hline $\mathrm{C}(323)$ & $0.2601(6)$ & $-0.2178(4)$ & $0.4814(2)$ & $0.035(2)$ \\
\hline$C(324)$ & $0.3783(6)$ & $-0.2679(4)$ & $0.4525(3)$ & $0.040(2)$ \\
\hline$C(325)$ & $0.4514(6)$ & $-0.2129(4)$ & $0.4201(3)$ & $0.0396(19)$ \\
\hline$C(326)$ & $0.4051(5)$ & $-0.1064(4)$ & $0.4165(2)$ & $0.0296(18)$ \\
\hline $\mathrm{C}(331)$ & $0.0793(5)$ & $0.1420(4)$ & $0.4035(2)$ & $0.0235(15)$ \\
\hline$C(332)$ & $0.0318(5)$ & $0.2500(4)$ & $0.3917(2)$ & $0.0292(18)$ \\
\hline $\mathrm{C}(333)$ & $-0.0821(5)$ & $0.3028(4)$ & $0.3624(3)$ & $0.0363(18)$ \\
\hline C(334) & $-0.1475(6)$ & $0.2490(5)$ & $0.3440(3)$ & $0.042(2)$ \\
\hline $\mathrm{C}(335)$ & $-0.0988(5)$ & $0.1427(5)$ & $0.3538(3)$ & $0.039(2)$ \\
\hline$C(336)$ & $0.0140(5)$ & $0.0883(4)$ & $0.3848(2)$ & $0.0310(18)$ \\
\hline $\mathrm{C}(341)$ & $0.1878(5)$ & $0.1052(4)$ & $0.5235(2)$ & $0.0243(16)$ \\
\hline $\mathrm{C}(342)$ & $0.2697(5)$ & $0.0378(4)$ & $0.5680(2)$ & $0.0310(18)$ \\
\hline$C(343)$ & $0.2472(6)$ & $0.0557(4)$ & $0.6290(3)$ & $0.038(2)$ \\
\hline$C(344)$ & $0.1427(6)$ & $0.1409(5)$ & $0.6453(3)$ & $0.043(2)$ \\
\hline$C(345)$ & $0.0626(6)$ & $0.2090(4)$ & $0.6010(3)$ & $0.041(2)$ \\
\hline $\mathrm{C}(346)$ & $0.0849(5)$ & $0.1912(4)$ & $0.5405(2)$ & $0.0312(18)$ \\
\hline
\end{tabular}


Table S4. Thermal parameters for $\left[\left(\mathrm{C}_{6} \mathrm{H}_{5}\right)_{4} \mathrm{P}\right]_{3}\left(\mathrm{O}_{3} \mathrm{SeOCH}_{2} \mathrm{OSeO}_{3}\right)\left(\mathrm{HSeO}_{4}\right)$

\begin{tabular}{|c|c|c|c|c|c|c|}
\hline Name & $\mathrm{U}(1,1)$ & $\mathrm{U}(2,2)$ & $\mathrm{U}(3,3)$ & $\mathrm{U}(1,2)$ & $\mathrm{U}(1,3)$ & $\mathrm{U}(2,3)$ \\
\hline$\overline{\operatorname{Se}(1)}$ & $0.0641(4)$ & $0.0308(3)$ & $0.0559(4)$ & $-0.0190(3)$ & $-0.0210(3)$ & $-0.0092(3)$ \\
\hline $\operatorname{Se}(2)$ & $0.0397(3)$ & $0.0332(3)$ & $0.0280(3)$ & $-0.0202(3)$ & $-0.0027(2)$ & $-0.0048(2)$ \\
\hline $\operatorname{Se}(3)$ & $0.0410(4)$ & $0.0525(4)$ & $0.0378(4)$ & $-0.0057(3)$ & $-0.0083(3)$ & $-0.0096(3)$ \\
\hline $\mathrm{P}(1)$ & $0.0272(7)$ & $0.0212(6)$ & $0.0205(6)$ & $-0.0092(5)$ & $-0.0035(5)$ & $-0.0018(5)$ \\
\hline $\mathrm{P}(2)$ & $0.0247(6)$ & $0.0189(6)$ & $0.0222(6)$ & $-0.0056(5)$ & $-0.0049(5)$ & $-0.0044(5)$ \\
\hline $\mathrm{P}(3)$ & $0.0212(6)$ & $0.0201(6)$ & $0.0219(6)$ & $-0.0050(5)$ & $-0.0007(5)$ & $-0.0037(5)$ \\
\hline $\mathrm{O}(11)$ & $0.137(7)$ & $0.079(5)$ & $0.150(7)$ & $-0.069(5)$ & $0.023(5)$ & $-0.008(5)$ \\
\hline $\mathrm{O}(12)$ & $0.176(7)$ & $0.062(4)$ & $0.066(4)$ & $-0.052(4)$ & $0.039(4)$ & $-0.035(3)$ \\
\hline $\mathrm{O}(13)$ & $0.126(7)$ & $0.238(11)$ & $0.089(5)$ & $0.065(7)$ & $-0.054(5)$ & $-0.105(6)$ \\
\hline $\mathrm{O}(14)$ & $0.093(6)$ & $0.286(13)$ & $0.121(7)$ & $-0.122(8)$ & $-0.032(5)$ & $0.067(7)$ \\
\hline $\mathrm{O}(21)$ & $0.086(4)$ & $0.037(2)$ & $0.041(2)$ & $-0.028(2)$ & $0.011(2)$ & $-0.013(2)$ \\
\hline $\mathrm{O}(24)$ & $0.083(5)$ & $0.145(7)$ & $0.096(5)$ & $-0.030(5)$ & $0.002(4)$ & $0.017(5)$ \\
\hline $\mathrm{O}(31)$ & $0.087(5)$ & $0.102(5)$ & $0.155(7)$ & $0.026(4)$ & $-0.066(5)$ & $-0.056(5)$ \\
\hline $\mathrm{O}(32)$ & $0.093(4)$ & $0.040(3)$ & $0.054(3)$ & $-0.020(3)$ & $-0.019(3)$ & $-0.013(2)$ \\
\hline $\mathrm{O}(33)$ & $0.095(5)$ & $0.139(6)$ & $0.063(4)$ & $-0.065(4)$ & $0.020(3)$ & $-0.053(4)$ \\
\hline $\mathrm{O}(34)$ & $0.095(4)$ & $0.094(4)$ & $0.059(3)$ & $-0.060(4)$ & $-0.024(3)$ & $0.011(3)$ \\
\hline $\mathrm{O}(22 \mathrm{~A})$ & $0.111(16)$ & $0.044(9)$ & $0.084(12)$ & $-0.063(10)$ & $0.057(10)$ & $-0.037(8)$ \\
\hline $\mathrm{O}(22 \mathrm{~B})$ & $0.063(5)$ & $0.037(4)$ & $0.045(4)$ & $-0.019(3)$ & $-0.005(3)$ & $0.011(3)$ \\
\hline $\mathrm{O}(23 \mathrm{~A})$ & $0.040(8)$ & $0.066(10)$ & $0.030(7)$ & $-0.009(7)$ & $-0.013(6)$ & $-0.016(6)$ \\
\hline $\mathrm{O}(23 \mathrm{~B})$ & $0.052(5)$ & $0.103(7)$ & $0.072(6)$ & $-0.030(5)$ & $-0.025(4)$ & $-0.002(5)$ \\
\hline $\mathrm{C}(1 \mathrm{~B})$ & $0.014(4)$ & $0.49(3)$ & $0.111(10)$ & $-0.048(9)$ & $-0.032(5)$ & $0.095(14)$ \\
\hline $\mathrm{C}(111)$ & $0.037(3)$ & $0.023(3)$ & $0.020(2)$ & $-0.009(2)$ & $-0.007(2)$ & $-0.004(2)$ \\
\hline $\mathrm{C}(112)$ & $0.046(3)$ & $0.031(3)$ & $0.028(3)$ & $-0.020(3)$ & $0.001(2)$ & $-0.006(2)$ \\
\hline $\mathrm{C}(113)$ & $0.063(4)$ & $0.033(3)$ & $0.030(3)$ & $-0.028(3)$ & $0.000(3)$ & $-0.007(2)$ \\
\hline$C(114)$ & $0.061(4)$ & $0.022(3)$ & $0.041(3)$ & $-0.010(3)$ & $-0.013(3)$ & $-0.006(2)$ \\
\hline $\mathrm{C}(115)$ & $0.038(3)$ & $0.032(3)$ & $0.050(4)$ & $-0.001(3)$ & $-0.009(3)$ & $-0.014(3)$ \\
\hline$C(116)$ & $0.034(3)$ & $0.026(3)$ & $0.035(3)$ & $-0.010(2)$ & $-0.010(2)$ & $-0.005(2)$ \\
\hline $\mathrm{C}(121)$ & $0.027(3)$ & $0.021(2)$ & $0.024(3)$ & $-0.007(2)$ & $-0.004(2)$ & $0.000(2)$ \\
\hline $\mathrm{C}(122)$ & $0.031(3)$ & $0.034(3)$ & $0.029(3)$ & $-0.012(2)$ & $-0.007(2)$ & $0.001(2)$ \\
\hline $\mathrm{C}(123)$ & $0.036(3)$ & $0.041(3)$ & $0.045(3)$ & $-0.017(3)$ & $-0.007(3)$ & $-0.008(3)$ \\
\hline $\mathrm{C}(124)$ & $0.034(3)$ & $0.029(3)$ & $0.045(3)$ & $-0.015(2)$ & $0.006(3)$ & $-0.003(3)$ \\
\hline$C(125)$ & $0.039(3)$ & $0.027(3)$ & $0.030(3)$ & $-0.008(2)$ & $0.007(2)$ & $-0.004(2)$ \\
\hline$C(126)$ & $0.032(3)$ & $0.026(3)$ & $0.025(3)$ & $-0.007(2)$ & $-0.003(2)$ & $-0.005(2)$ \\
\hline $\mathrm{C}(131)$ & $0.027(3)$ & $0.024(2)$ & $0.022(2)$ & $-0.011(2)$ & $-0.005(2)$ & $0.003(2)$ \\
\hline $\mathrm{C}(132)$ & $0.029(3)$ & $0.034(3)$ & $0.028(3)$ & $-0.011(2)$ & $-0.004(2)$ & $-0.004(2)$ \\
\hline C(133) & $0.027(3)$ & $0.038(3)$ & $0.035(3)$ & $-0.007(2)$ & $-0.004(2)$ & $0.000(2)$ \\
\hline C(134) & $0.031(3)$ & $0.043(3)$ & $0.035(3)$ & $-0.018(3)$ & $-0.008(2)$ & $0.006(3)$ \\
\hline$C(135)$ & $0.043(3)$ & $0.049(4)$ & $0.033(3)$ & $-0.019(3)$ & $-0.013(3)$ & $-0.006(3)$ \\
\hline$C(136)$ & $0.035(3)$ & $0.040(3)$ & $0.037(3)$ & $-0.012(3)$ & $-0.008(3)$ & $-0.010(3)$ \\
\hline $\mathrm{C}(141)$ & $0.028(3)$ & $0.022(2)$ & $0.022(2)$ & $-0.008(2)$ & $-0.006(2)$ & $-0.001(2)$ \\
\hline$C(142)$ & $0.040(3)$ & $0.021(3)$ & $0.027(3)$ & $-0.012(2)$ & $-0.006(2)$ & $0.001(2)$ \\
\hline$C(143)$ & $0.042(3)$ & $0.030(3)$ & $0.032(3)$ & $-0.012(2)$ & $-0.007(2)$ & $-0.009(2)$ \\
\hline C(144) & $0.043(3)$ & $0.036(3)$ & $0.023(3)$ & $-0.013(3)$ & $-0.003(2)$ & $-0.005(2)$ \\
\hline$C(145)$ & $0.043(3)$ & $0.032(3)$ & $0.021(3)$ & $-0.007(2)$ & $-0.002(2)$ & $0.001(2)$ \\
\hline$C(146)$ & $0.039(3)$ & $0.022(3)$ & $0.025(3)$ & $-0.010(2)$ & $-0.004(2)$ & $-0.004(2)$ \\
\hline $\mathrm{C}(211)$ & $0.026(3)$ & $0.023(2)$ & $0.023(2)$ & $-0.010(2)$ & $-0.003(2)$ & $-0.001(2)$ \\
\hline$C(212)$ & $0.029(3)$ & $0.029(3)$ & $0.026(3)$ & $-0.006(2)$ & $-0.003(2)$ & $-0.005(2)$ \\
\hline $\mathrm{C}(213)$ & $0.024(3)$ & $0.036(3)$ & $0.032(3)$ & $-0.002(2)$ & $0.000(2)$ & $-0.004(2)$ \\
\hline $\mathrm{C}(214)$ & $0.025(3)$ & $0.035(3)$ & $0.034(3)$ & $-0.010(2)$ & $-0.007(2)$ & $0.004(2)$ \\
\hline$C(215)$ & $0.042(3)$ & $0.037(3)$ & $0.033(3)$ & $-0.018(3)$ & $-0.014(3)$ & $-0.003(2)$ \\
\hline
\end{tabular}


Table S4. (Continued)

\begin{tabular}{|c|c|c|c|c|c|c|}
\hline Name & $\mathrm{U}(1,1)$ & $\mathrm{U}(2,2)$ & $\mathrm{U}(3,3)$ & $\mathrm{U}(1,2)$ & $\mathrm{U}(1,3)$ & $\mathrm{U}(2,3)$ \\
\hline $\bar{C}(221)$ & $0.032(3)$ & $0.017(2)$ & $0.021(2)$ & $-0.007(2)$ & $-0.007(2)$ & $-0.0012(19$ \\
\hline $\mathrm{C}(222)$ & $0.037(3)$ & $0.027(3)$ & $0.030(3)$ & $-0.011(2)$ & $-0.001(2)$ & $-0.007(2)$ \\
\hline $\mathrm{C}(223)$ & $0.049(3)$ & $0.026(3)$ & $0.032(3)$ & $-0.018(3)$ & $0.000(3)$ & $-0.006(2)$ \\
\hline $\mathrm{C}(224)$ & $0.053(4)$ & $0.019(3)$ & $0.032(3)$ & $-0.007(2)$ & $-0.013(3)$ & $-0.005(2)$ \\
\hline $\mathrm{C}(225)$ & $0.035(3)$ & $0.027(3)$ & $0.041(3)$ & $-0.001(2)$ & $-0.007(3)$ & $-0.012(2)$ \\
\hline $\mathrm{C}(226)$ & $0.029(3)$ & $0.026(3)$ & $0.030(3)$ & $-0.008(2)$ & $-0.007(2)$ & $-0.008(2)$ \\
\hline $\mathrm{C}(231)$ & $0.026(3)$ & $0.018(2)$ & $0.036(3)$ & $-0.005(2)$ & $-0.003(2)$ & $-0.002(2)$ \\
\hline $\mathrm{C}(232)$ & $0.030(3)$ & $0.022(3)$ & $0.037(3)$ & $-0.003(2)$ & $0.000(2)$ & $-0.006(2)$ \\
\hline $\mathrm{C}(233)$ & $0.038(3)$ & $0.026(3)$ & $0.041(3)$ & $-0.001(2)$ & $0.012(3)$ & $-0.001(2)$ \\
\hline $\mathrm{C}(234)$ & $0.032(3)$ & $0.032(3)$ & $0.060(4)$ & $-0.009(3)$ & $0.006(3)$ & $0.009(3)$ \\
\hline $\mathrm{C}(235)$ & $0.031(3)$ & $0.031(3)$ & $0.068(5)$ & $-0.015(3)$ & $-0.006(3)$ & $0.000(3)$ \\
\hline $\mathrm{C}(236)$ & $0.031(3)$ & $0.028(3)$ & $0.047(3)$ & $-0.010(2)$ & $-0.013(3)$ & $0.000(2)$ \\
\hline $\mathrm{C}(241)$ & $0.027(3)$ & $0.029(3)$ & $0.029(3)$ & $-0.002(2)$ & $-0.008(2)$ & $-0.011(2)$ \\
\hline $\mathrm{C}(242)$ & $0.037(3)$ & $0.035(3)$ & $0.044(3)$ & $-0.008(3)$ & $-0.010(3)$ & $-0.019(3)$ \\
\hline $\mathrm{C}(243)$ & $0.047(4)$ & $0.052(4)$ & $0.050(4)$ & $-0.004(3)$ & $-0.017(3)$ & $-0.031(3)$ \\
\hline $\mathrm{C}(244)$ & $0.052(4)$ & $0.089(6)$ & $0.047(4)$ & $-0.009(4)$ & $-0.005(3)$ & $-0.044(4)$ \\
\hline $\mathrm{C}(245)$ & $0.070(5)$ & $0.078(5)$ & $0.025(3)$ & $-0.015(4)$ & $-0.005(3)$ & $-0.007(3)$ \\
\hline $\mathrm{C}(246)$ & $0.053(4)$ & $0.039(3)$ & $0.026(3)$ & $-0.012(3)$ & $-0.005(3)$ & $-0.007(2)$ \\
\hline $\mathrm{C}(311)$ & $0.022(2)$ & $0.020(2)$ & $0.028(3)$ & $-0.004(2)$ & $0.000(2)$ & $-0.004(2)$ \\
\hline $\mathrm{C}(312)$ & $0.026(3)$ & $0.027(3)$ & $0.029(3)$ & $-0.008(2)$ & $-0.001(2)$ & $-0.007(2)$ \\
\hline C(313) & $0.029(3)$ & $0.028(3)$ & $0.033(3)$ & $-0.008(2)$ & $0.005(2)$ & $-0.002(2)$ \\
\hline $\mathrm{C}(314)$ & $0.024(3)$ & $0.026(3)$ & $0.045(3)$ & $-0.009(2)$ & $0.000(2)$ & $0.003(2)$ \\
\hline $\mathrm{C}(315)$ & $0.033(3)$ & $0.028(3)$ & $0.044(3)$ & $-0.013(2)$ & $-0.012(3)$ & $-0.001(2)$ \\
\hline $\mathrm{C}(316)$ & $0.031(3)$ & $0.025(3)$ & $0.028(3)$ & $-0.007(2)$ & $-0.008(2)$ & $0.000(2)$ \\
\hline $\mathrm{C}(321)$ & $0.032(3)$ & $0.021(2)$ & $0.020(2)$ & $-0.006(2)$ & $-0.004(2)$ & $-0.004(2)$ \\
\hline C(322) & $0.034(3)$ & $0.031(3)$ & $0.026(3)$ & $-0.008(2)$ & $0.002(2)$ & $-0.007(2)$ \\
\hline C(323) & $0.056(4)$ & $0.027(3)$ & $0.024(3)$ & $-0.018(3)$ & $-0.004(3)$ & $-0.002(2)$ \\
\hline $\mathrm{C}(324)$ & $0.057(4)$ & $0.022(3)$ & $0.033(3)$ & $-0.005(3)$ & $-0.012(3)$ & $-0.002(2)$ \\
\hline $\mathrm{C}(325)$ & $0.043(3)$ & $0.032(3)$ & $0.031(3)$ & $0.001(3)$ & $0.002(3)$ & $-0.010(2)$ \\
\hline $\mathrm{C}(326)$ & $0.028(3)$ & $0.029(3)$ & $0.027(3)$ & $-0.006(2)$ & $-0.001(2)$ & $-0.003(2)$ \\
\hline $\mathrm{C}(331)$ & $0.022(2)$ & $0.025(3)$ & $0.021(2)$ & $-0.007(2)$ & $-0.002(2)$ & $-0.001(2)$ \\
\hline C(332) & $0.027(3)$ & $0.027(3)$ & $0.031(3)$ & $-0.008(2)$ & $-0.007(2)$ & $0.001(2)$ \\
\hline $\mathrm{C}(333)$ & $0.031(3)$ & $0.033(3)$ & $0.037(3)$ & $-0.006(2)$ & $-0.006(2)$ & $0.004(2)$ \\
\hline $\mathrm{C}(334)$ & $0.029(3)$ & $0.058(4)$ & $0.034(3)$ & $-0.014(3)$ & $-0.010(2)$ & $0.005(3)$ \\
\hline $\mathrm{C}(335)$ & $0.034(3)$ & $0.055(4)$ & $0.036(3)$ & $-0.026(3)$ & $-0.007(3)$ & $-0.005(3)$ \\
\hline C(336) & $0.034(3)$ & $0.032(3)$ & $0.028(3)$ & $-0.013(2)$ & $-0.001(2)$ & $-0.006(2)$ \\
\hline $\mathrm{C}(341)$ & $0.026(3)$ & $0.022(2)$ & $0.023(3)$ & $-0.007(2)$ & $0.000(2)$ & $-0.004(2)$ \\
\hline $\mathrm{C}(342)$ & $0.031(3)$ & $0.027(3)$ & $0.030(3)$ & $-0.003(2)$ & $-0.004(2)$ & $-0.008(2)$ \\
\hline $\mathrm{C}(343)$ & $0.052(4)$ & $0.033(3)$ & $0.025(3)$ & $-0.009(3)$ & $-0.012(3)$ & $-0.003(2)$ \\
\hline $\mathrm{C}(344)$ & $0.057(4)$ & $0.045(4)$ & $0.027(3)$ & $-0.017(3)$ & $0.000(3)$ & $-0.014(3)$ \\
\hline $\mathrm{C}(345)$ & $0.046(4)$ & $0.033(3)$ & $0.035(3)$ & $-0.001(3)$ & $0.003(3)$ & $-0.017(3)$ \\
\hline C(346) & $0.033(3)$ & $0.026(3)$ & $0.029(3)$ & $-0.003(2)$ & $-0.005(2)$ & $-0.006(2)$ \\
\hline
\end{tabular}

The form of the anisotropic temperature factor is:

$\exp \left[-2 p h^{2} a^{* 2} U(1,1)+k^{2} b^{* 2} U(2,2)+l^{2} c^{* 2} U(3,3)+2 h k a^{*} b^{*} U(1,2)+2 h l a^{*} c^{*} U(1,3)\right.$ $\left.+2 \mathrm{klb} \mathrm{c}^{*} \mathrm{U}(2,3)\right]$ where $\mathrm{a}^{*}, \mathrm{~b}^{*}$, and $\mathrm{c}^{*}$ are reciprocal lattice constants. 